Bond University

Research Repository

\title{
Downsides of face masks and possible mitigation strategies: a systematic review and meta- analysis
}

Bakhit, Mina; Krzyzaniak, Natalia; Scott, Anna Mae; Clark, Justin; Glasziou, Paul; Del Mar, Chris

Published in:

BMJ Open

DOI:

10.1136/bmjopen-2020-044364

Licence:

CC BY-NC

Link to output in Bond University research repository.

Recommended citation(APA):

Bakhit, M., Krzyzaniak, N., Scott, A. M., Clark, J., Glasziou, P., \& Del Mar, C. (2021). Downsides of face masks and possible mitigation strategies: a systematic review and meta-analysis. BMJ Open, 11(2), e044364.

[e044364]. https://doi.org/10.1136/bmjopen-2020-044364

\section{General rights}

Copyright and moral rights for the publications made accessible in the public portal are retained by the authors and/or other copyright owners and it is a condition of accessing publications that users recognise and abide by the legal requirements associated with these rights.

For more information, or if you believe that this document breaches copyright, please contact the Bond University research repository coordinator 


\title{
BMJ Open Downsides of face masks and possible mitigation strategies: a systematic review and meta-analysis
}

\author{
Mina Bakhit (D) , Natalia Krzyzaniak (D), Anna Mae Scott (D) , Justin Clark, \\ Paul Glasziou (D), Chris Del Mar
}

To cite: Bakhit M, Krzyzaniak N, Scott AM, et al. Downsides of face masks and possible mitigation strategies: a systematic review and meta-analysis. BMJ Open 2021;11:e044364. doi:10.1136/ bmjopen-2020-044364

- Prepublication history and additional material for this paper are available online. To view these files, please visit the journal online (http://dx.doi. org/10.1136/bmjopen-2020044364).

Received 02 September 2020 Revised 03 February 2021 Accepted 04 February 2021

Check for updates

(C) Author(s) (or their employer(s)) 2021. Re-use permitted under CC BY-NC. No commercial re-use. See rights and permissions. Published by BMJ.

Institute for Evidence-Based Healthcare, Bond University, Gold Coast, Queensland, Australia

Correspondence to

Dr Mina Bakhit;

mbakhit@bond.edu.au

\section{ABSTRACT}

Objective To identify, appraise and synthesise studies evaluating the downsides of wearing face masks in any setting. We also discuss potential strategies to mitigate these downsides.

Design Systematic review and meta-analysis.

Data sources PubMed, Embase, CENTRAL and EuropePMC were searched (inception-18 May 2020), and clinical registries were searched via CENTRAL. We also did a forward-backward citation search of the included studies.

Inclusion criteria We included randomised controlled trials and observational studies comparing face mask use to any active intervention or to control.

Data extraction and analysis Two author pairs independently screened articles for inclusion, extracted data and assessed the quality of included studies. The primary outcomes were compliance, discomforts, harms and adverse events of wearing face masks.

Results We screened 5471 articles, including 37 (40 references); 11 were meta-analysed. For mask wear adherence, $47 \%$ (95\% Cl 25\% to $68 \%$, $\mathrm{p}<0.0001)$, more people wore face masks in the face mask group compared with control; adherence was significantly higher $(26 \%, 95 \% \mathrm{Cl} 8 \%$ to $46 \%, \mathrm{p}<0.01)$ in the surgical/ medical mask group than in N95/P2 group. The largest number of studies reported on the discomfort and irritation outcome (20 studies); fewest reported on the misuse of masks, and none reported on mask contamination or risk compensation behaviour. Risk of bias was generally high for blinding of participants and personnel and low for attrition and reporting biases.

Conclusions There are insufficient data to quantify all of the adverse effects that might reduce the acceptability, adherence and effectiveness of face masks. New research on face masks should assess and report the harms and downsides. Urgent research is also needed on methods and designs to mitigate the downsides of face mask wearing, particularly the assessment of possible alternatives.

Systematic review registration Open Science Framework website https://osf.io/sa6kf/ (timestamp 2005-2020).

\section{INTRODUCTION}

Respiratory viruses are predominantly transmitted by aerosol, droplets and fomites. ${ }^{1}$ Face

\section{Strengths and limitations of this study}

- This is the first systematic review to investigate the downsides of wearing face masks.

- We included non-randomised study designs in addition to randomised controlled trials, as trials frequently under-reported or failed to report harms.

- We reported two deviations from the study protocol, relating to the measurement of effect and the subgroup analysis.

masks-such as surgical masks, N95 masks and face shields, and substitutes for surgical masks such as home-made cloth masks-are a physical barrier to aerosol and droplet transmission. During the COVID-19 pandemic, some jurisdictions have implemented policies mandating the use of masks in public places, on public transport or in other crowded environments to prevent people becoming infected or infecting others.

While most health organisations mandate the use of face masks by health workers when caring for patients during a pandemic, recommendations for mask wear in the community vary widely and include: use by all, use only in certain situations (eg, on public transport or in crowded places where social distancing is not possible), and no specific recommendations about mask use.

Several trials have evaluated the impact on respiratory infections by use of surgical and N95 masks, which may, at best, modestly reduce acute respiratory infection transmission. ${ }^{2-4}$ Population observational studies suggest that masks have a more substantial effect. ${ }^{5}$ However, the downsides of maskwearing were either not considered or not reported in most studies. Most trials have focused on face masks protecting the wearer, rather than others in the community, are often low powered, and include confounding factors resulting in the current 
evidence for the efficacy of face masks being less than adequate. ${ }^{6}$

The current controversies, mixed messaging and debate over the use of face masks to prevent the spread of COVID-19 warrants further investigation into their use. Anecdotal evidence, and some studies, suggest that there may be a variety of downsides arising from mask use, including: discomfort, sense of difficulty breathing and communication problems particularly for those who use lip reading. ${ }^{67}$ Our aim is to systematically identify and summarise these downsides to assist policymakers when formulating mask-wearing policies in public settings. We also discuss potential strategies to mitigate downsides of mask-wearing.

\section{METHODS}

This systematic review is reported following the Preferred Reporting Items for Systematic Reviews and MetaAnalyses statement. ${ }^{8}$ We followed the ' 2 week systematic review' processes for the review. ${ }^{9}$ The review protocol was developed prospectively and uploaded to the Open Science Framework data on 20 May 2020 (see: https:// osf.io/sa6kf/). Deviations from the protocol are reported in the Methods section and highlighted as a limitation in the Discussion section.

\section{Inclusion criteria}

We included studies of people of any age or gender, in any setting. We included studies of any face covering aimed at reducing virus transmission, including surgical masks, N95 masks, cloth masks (both homemade and commercially available) (see online supplemental appendix 1 for a summary of included face masks and their intended purpose). Studies evaluating the use of masks for non-virus transmission purposes (eg, valved masks for preventing inhalation of airborne contaminants such as particles, gases or vapours) were excluded (see online supplemental appendix 2 for a complete list of excluded face masks).

We included studies comparing the use of face mask to any active intervention (eg, another mask or another intervention such as hand washing) and studies comparing the use of face mask to control (comprising standard practice, ie, face masks not explicitly provided to study group) in situations where their use was not mandatory.

We included only primary studies, that is, randomised controlled trials (RCTs) and observational studies of any design. We intentionally included this range of study types to identify appropriate data that corresponded with the listed outcomes. For example, surveys are appropriate for identifying frequency of discomfort, and breathing trials are appropriate for understanding physiological changes. We excluded studies that could not provide a quantitative estimate of the size or frequency of adverse effects such as case reports, case series, as well as qualitative studies, and reviews.

\section{Box 1 List of extracted information}

- General information: study authors, location, study design, duration, aim and setting.

- Participants: health status, disease (if applicable), sample size, age, gender, smoker status and comorbidities.

- Intervention and comparator(s): number of participants, type of face covering, adjunct interventions, number of face coverings used, duration of use and disposal.

- Outcomes: definition, measurement instrument, number of adverse events or harms reported (the outcomes were discomforts, harms and adverse events of wearing face masks, adherence to face mask wearing, misuse of masks, discomfort and other physical irritation from masks, psychological outcomes (eg, fear), dyspnoea (difficulty breathing and shortness of breath) and other physiological impacts, communication impacts and mask contamination).

\section{Search strategies}

We searched PubMed, Embase, Cochrane CENTRAL, EuropePMC (inception-18 May 2020). The search string was designed for PubMed and translated for use in other databases using the Polyglot Search Translator (online supplemental appendix 3). ${ }^{10}$ Clinical trial registries were searched via Cochrane CENTRAL, which includes the WHO International Clinical Trials Registry Platform (ICTRP) and clinicaltrials.gov. On 22 May 2020, we conducted a backwards and forwards citation analysis in Scopus, on all of the included studies.

No restrictions by language or publication date were imposed. We included publications that were published in full; abstract-only publications were included if they had an accompanying record (eg, trial registry record or another public report), with additional information.

\section{Study selection and screening}

Two author pairs (MB and NK, AMS and JC) independently screened the titles and abstracts against the inclusion criteria. One author (JC) retrieved full text, and two author pairs (MB and NK, AMS and JC) screened the full texts. Disagreements were resolved by discussion or a third author (PG or CDM).

\section{Data extraction}

A data extraction form was piloted on three studies. Two author pairs (MB and NK, AMS and JC) extracted the data (see box 1).

\section{Assessment of risk of bias in included studies}

Two author pairs (MB and NK, AMS and JC) independently assessed the risk of bias using the Cochrane Risk of Bias Tool. ${ }^{11}$ Disagreements were resolved by discussion or a third author (CDM or PG). Each potential source of bias was graded as low, high or unclear, and judgements were supported by a quote from the study.

\section{Measurement of effect and data synthesis}

Where feasible ( $\geq 2$ studies reporting the same outcome), we expressed outcome measures as odds ratios (ORs) with 95\% CIs, analysed using Review Manager (RevMan 
V.5). Anticipating considerable heterogeneity among the included studies, we used a random effects model. We reported the adherence to face mask wear using risk difference (RD) rather than OR to more clearly convey the differences in adherence between the intervention and control group (not prespecified in the protocol).

When meta-analysis was not possible or appropriate, we followed the guidance of the Cochrane Collaboration (Cochrane Handbook Section 12.2). ${ }^{11}$ When narrative synthesis was required, we reported the results separately for each harm or adverse outcome.

The individual was used as the unit of analysis, where possible; otherwise, we extracted the information as it was presented, for example, the number of harms in each group. We attempted to contact investigators or study sponsors to provide missing data.

We used the $\mathrm{I}^{2}$ statistic to measure heterogeneity. Because we included fewer than 10 trials, we did not create a funnel plot.

We did not prespecify subgroup or sensitivity analyses. However, as data were available, we conducted a subgroup analysis of adherence to mask-wearing by studies that evaluated face mask wear alone and those evaluating face mask together with hand washing.

\section{Patient and public involvement}

Patients and the public were not involved in the design and conduct of this review.

\section{RESULTS}

Database searches identified 4691 publications, supplemented with 2035 references from forward and backward citation searches and other sources, totalling 6726 . After deduplication, 5471 references were screened by title and abstract; we full-text screened 214 references, excluding 174 (see online supplemental appendix 4 for a list of excluded studies with reasons). We included 40 articles $^{12-51}$ corresponding to 37 studies (table 1 reports the characteristics of included studies) and meta-analysed 11 studies. ${ }^{15} 21222631-34414547$ (figure 1).

\section{Risk of bias}

Inclusion of both observational studies and RCTs could explain the high risk of bias across the included studies. Reporting of sequence generation, allocation concealment and blinding of outcome assessment was poor in $20 \%-30 \%$ of studies. Due to the nature of interventions, blinding of participants was rare. For RCTs, we reported blinding of outcome assessment for the main trial (not the adverse events), as some outcomes were lab confirmed and were considered of low risk. We found no evidence of incomplete outcome data or selective reporting of outcomes. Funding statement, funder's role and authors' conflict of interests were adequately reported in most studies (see figure 2, and figure 3 in online supplemental appendix 5).

\section{Adherence to face mask wearing}

Seventeen studies (14 RCTs, 3 observational) ${ }^{10} 1317$ reported on adherence to face mask wearing; of these 11 studies had sufficient data to pool and were meta-analysed.

\section{Face mask versus control comparison}

Comparison of face masks with control was subgrouped into studies comparing face mask alone versus control and studies of face mask plus hand washing versus control (figure 3).

Face masks alone versus control (five studies) showed the face mask group had a significantly higher face mask wear compared with control (RD: $0.46,95 \%$ CI 0.24 to $0.67, \mathrm{p}<0.0001)$. Studies evaluating face mask plus hand washing versus control $(n=3)$ similarly showed significantly higher face mask wear in the face mask group (RD: 0.47 (95\% CI 0.07 to $0.88, \mathrm{p}<0.0001$ ).

Overall, seven studies (3303 participants) compared face masks with control. Face mask wear was $47 \%$ higher in the face mask group, although heterogeneity was very high (RD: $0.47,95 \%$ CI 0.25 to $0.68, \mathrm{p}<0.0001, \mathrm{I}^{2}=98 \%$.)

We explored the possible sources of heterogeneity. Excluding studies with three or more domains at high risk of bias did not decrease heterogeneity $\left(I^{2}=96 \%\right.$ for face mask vs control; $99 \%$ for face mask plus hand washing vs control) (figure 4, online supplemental appendix 5). We excluded study population as the source of heterogeneity, because subgrouping studies by those in a community/ household settings (which included both index cases and their contacts) versus those in a hospital setting (which included healthy healthcare workers) likewise did not decrease heterogeneity ( $I^{2}=99 \%$ for community/household studies, and $97 \%$ for hospital studies) (figure 5, online supplemental appendix 5). We excluded intervention and control as sources of heterogeneity, since all studies compared medical/surgical masks to control (no mask), although some mask-wear did occur in the control groups.

We consider the outcome measurement to be the most likely other source of heterogeneity. All studies relied on self-reporting of the outcome; only one verified this by counting the number of masks used. ${ }^{21}$ What was considered 'wearing a face mask' varied: it was unclear, ${ }^{15} 2145$ involved wearing a face mask 'always or mostly/often', 2247 included wearing a face mask while on hospital property, performing a healthcare worker role ${ }^{26}$ and included face mask wear during a shift for $70 \%$ of time or more. ${ }^{32}$ The follow-up was very short (5-9 days) for four studies ${ }^{152} 2247$; it was longer for three studies (21-77 days). ${ }^{263245}$

\section{Face mask (surgical/medical) versus face mask (N92/P2 mask)}

Four studies (7960 participants) compared adherence for different face masks. ${ }^{31} 33341$ Face mask wear was significantly higher in the surgical/medical face mask group than in the N95/P2 group, OR=1.26 (95\% CI 1.08 to 1.46, $\mathrm{p}<0.01)$. Heterogeneity was very low $\left(\mathrm{I}^{2}=27 \%\right)$ (figure 4 ). 


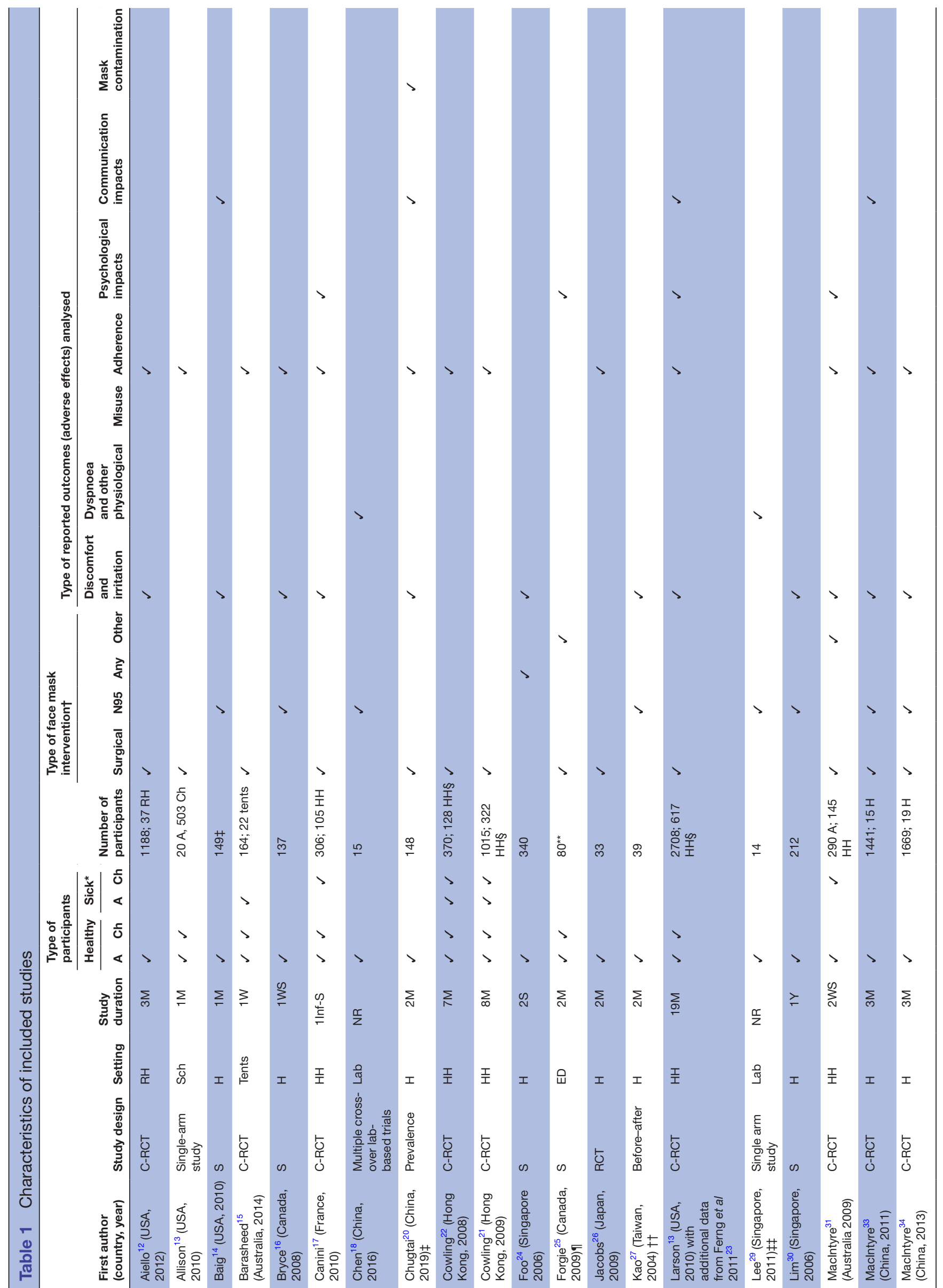




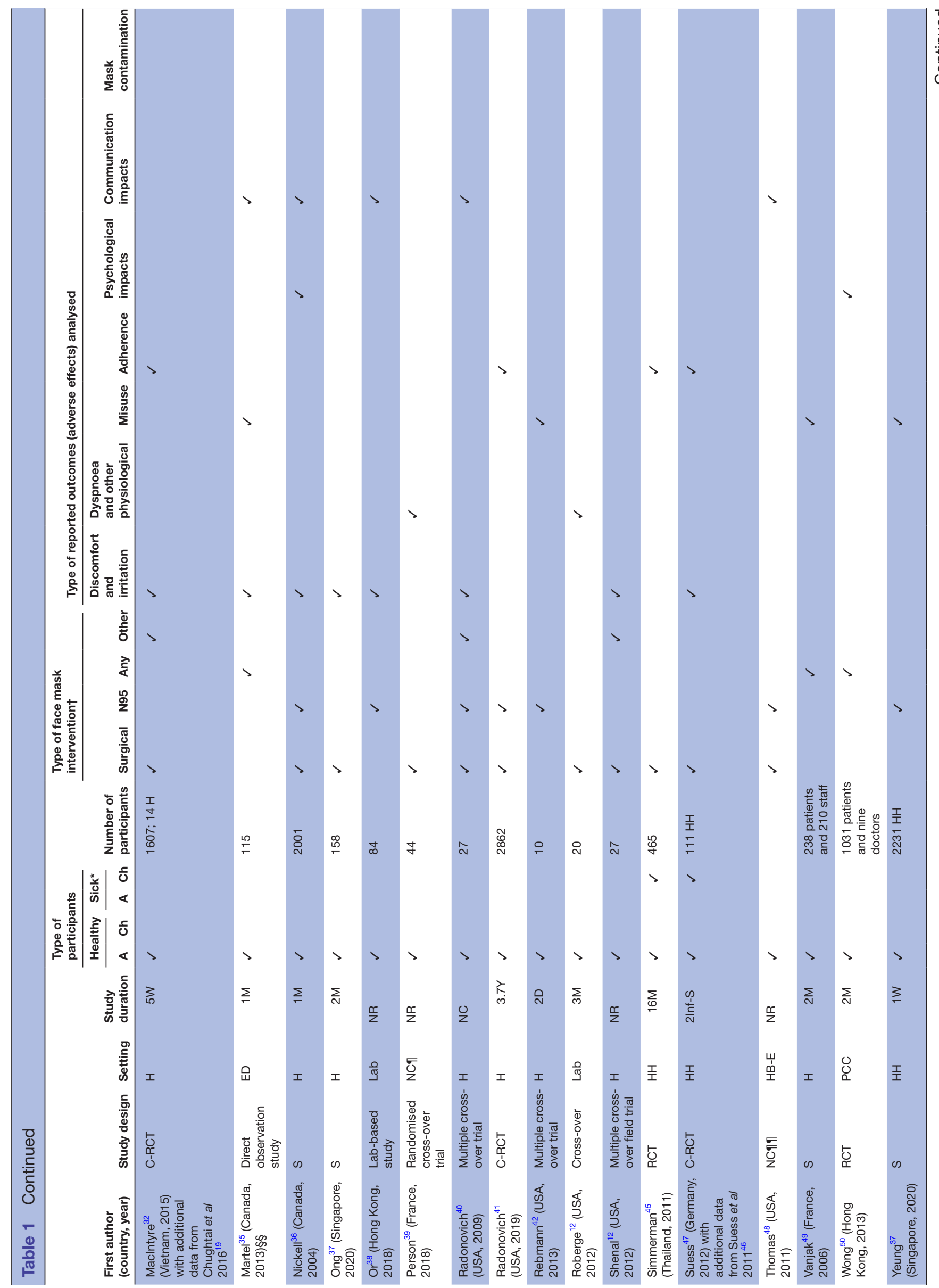




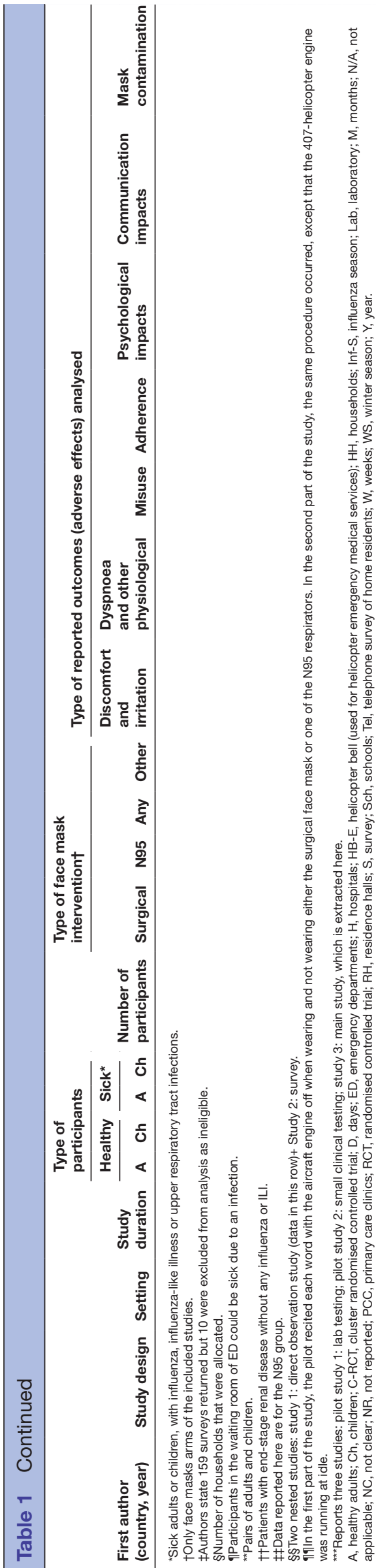

Studies not included in the meta-analysis Randomised controlled trials $(n=3)$

One study in a residential hall setting reported similar duration of face mask wear per day in the face mask alone group versus face mask plus hand washing group (mean of 5.08 and 5.04 hours/day, respectively) ${ }^{12}$ Another in a household setting reported that within the face mask group, there were no significant differences between individuals with ILI among contacts versus no ILI among contacts, for face mask use. ${ }^{17}$ Finally, 22 of 44 households randomised to the 'education with sanitiser and face masks' arm reported having used a mask within 48 hours of episode onset. ${ }^{28}$

\section{Observational studies $(n=3)$}

In an elementary school setting, approximately twice as many teachers as students wore face masks. ${ }^{13}$ A mean compliance score with N95 use guidelines was 21.2 (on a 25-point scale) among frequent users of N95 respirators in a hospital setting. ${ }^{16}$ Another study among healthcare workers found that majority of survey respondents (91\%) wore one to two masks per day (range 1-4). ${ }^{20}$

\section{Misuse}

Mask misuse appears less studied than other harms and discomforts. A study of 10 nurses observed for $10 \mathrm{~min} /$ hour over two shifts found that they touched their face two to three times per hour, their mask five times per hour and their eyes once per 2 hours, when observed by students. ${ }^{42}$ In a study of health workers, 13 of the 53 who responded (25\%) reported wearing masks only covering their mouth, not their nose. ${ }^{49}$ One study conducted in two hospitals, ${ }^{35}$ observed triage nurse behaviour with 118 patients with fever and cough, found that in only $18 \%$ of cases the nurses informed patients of the need to wear a mask, and in half of those, gave instruction on the need to cover both mouth and nose. A cross-sectional study evaluating the proficiency of the Singaporean public in wearing N95 masks found only 90/714 subjects passed the visual mask fit test; the most common criteria performed incorrectly were: strap placement, leaving a visible gap between the mask and skin and tightening the nose-clip. ${ }^{51}$

\section{Discomfort and irritation}

Several RCTs of specifically measured mask wear discomfort, ${ }^{17} 31-3347$ but most only recorded spontaneously reported events ${ }^{122834}$ or did not report any. ${ }^{15212226414550} \mathrm{~A}$ trial of household index influenza cases allocated to wear masks or no mask found the 51 allocated to masks wore them on average 3.8 hours/day and $38(76 \%)$ reported discomfort (table 2). ${ }^{17} \mathrm{~A}$ study of healthcare workers in Beijing asked to wear masks for their full shift found $84 \%$ complained of at least one problem (table 2) ${ }^{20}$ In a German household study, 65/172 participants reported problems with mask wearing, most commonly warmth, pain and shortness of breath. ${ }^{47}$

In a trial of healthcare workers comparing surgical and N95 masks to prevent influenza, more workers found 


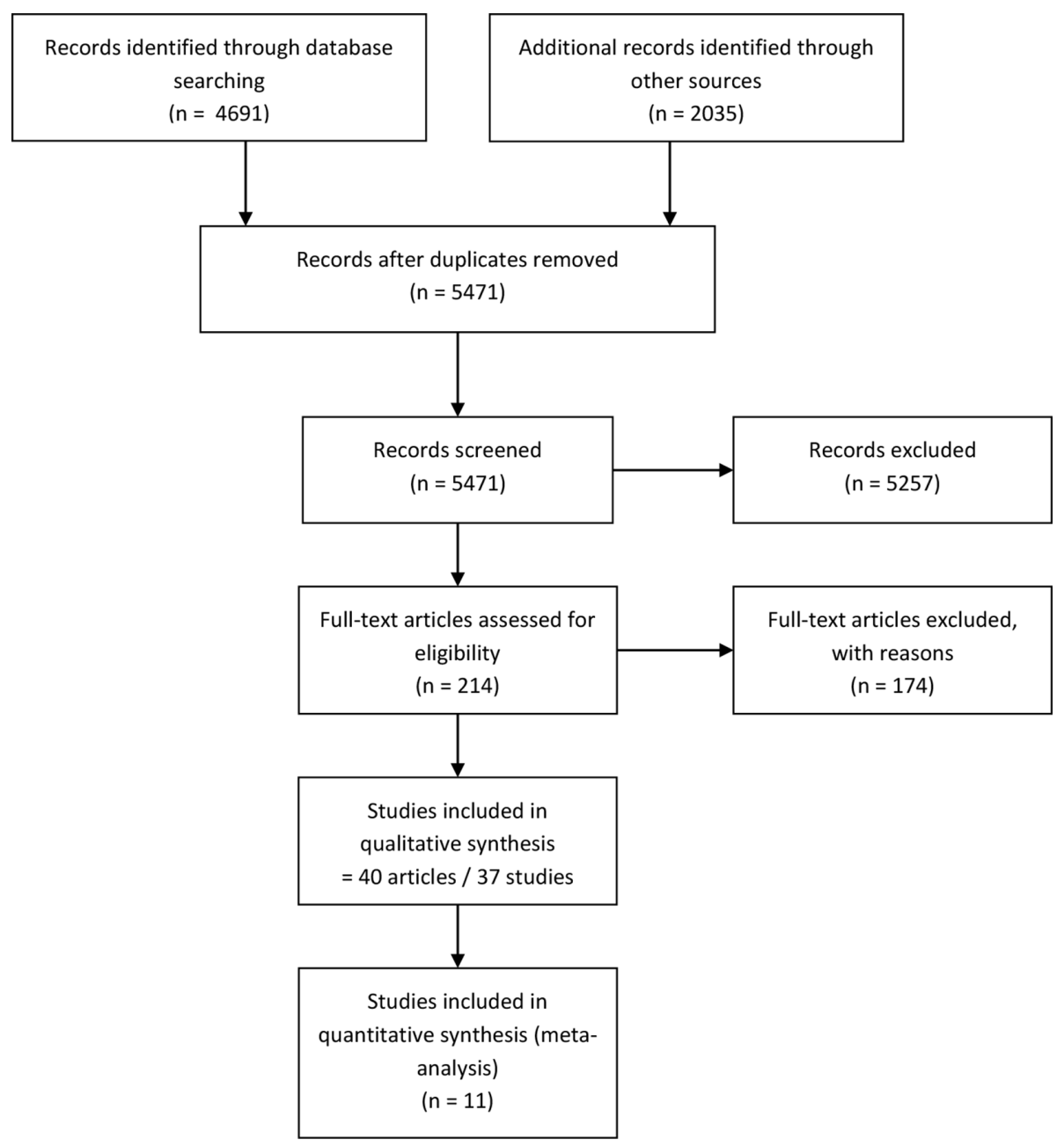

Figure 1 PRISMA flow diagram.

the N95 uncomfortable (42\%) than the medical mask $(10 \%)$ when worn an average of 5 hours per day, ${ }^{33}$ with significant differences in headaches, difficulty breathing and pressure on the nose (table 2). A trial of cloth versus medical masks in healthcare workers found similar rates of discomfort. ${ }^{32}$ A community trial comparing surgical and P2 (N95) masks found $>50 \%$ reporting concerns, primarily discomfort, with similar rates $(15 \%$ vs $17 \%)$ across groups. ${ }^{31}$
Discomfort increases with duration of mask wearing. A cross-over field trial of 27 healthcare workers found increased discomfort over time; half the subjects were unwilling to wear a medical mask for the full 8-hour shift despite regularly wearing them for short periods. ${ }^{44}$

Two surveys of healthcare staff in Singapore during the SARS epidemic assessed headache and skin reactions. ${ }^{24} 30$ In one survey, 79/212 (37\%) reported face mask associated headaches, $26(33 \%)$ reported headache frequency

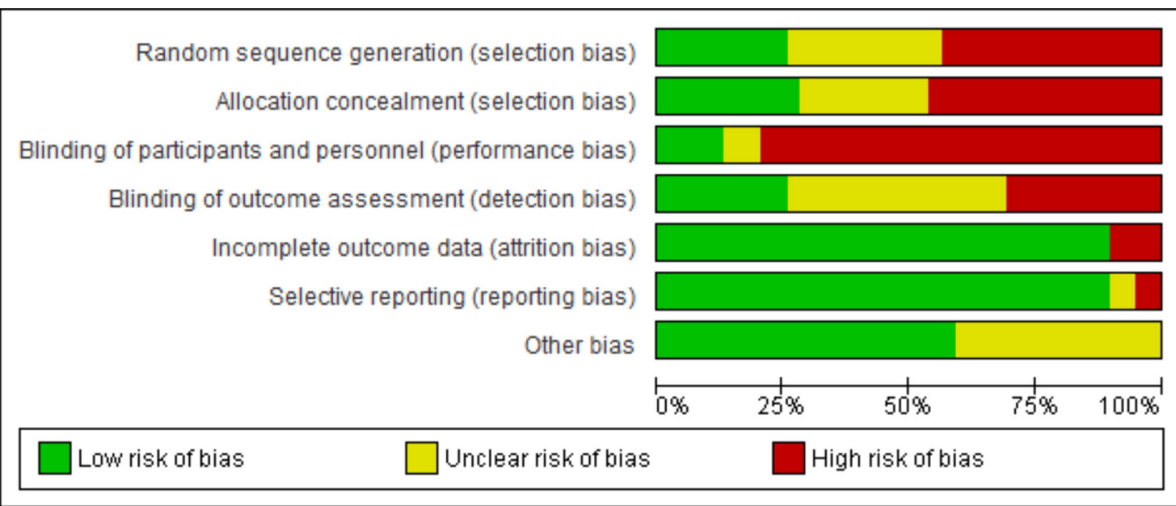

Figure 2 Risk of bias graph: review authors' judgements about each risk of bias item presented as percentages across all included studies. 


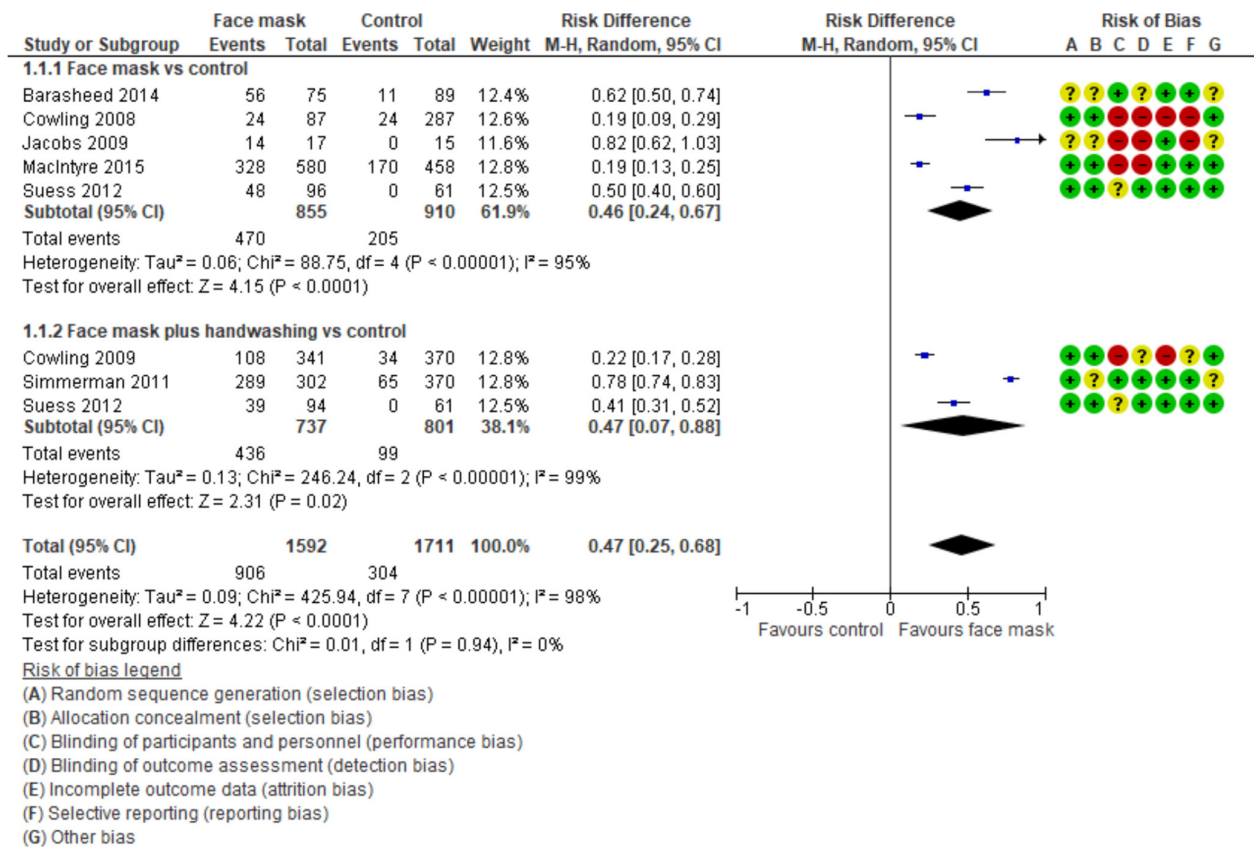

Figure 3 Comparison of adherence to face masks versus control.

exceeding six times/month and 6 had taken sick leave. ${ }^{30}$ Another survey of healthcare workers in Singapore found that of the 307 staff who used masks regularly, $60 \%$ reported acne, $51 \%$ facial itch and $36 \%$ rash from N95 mask use. ${ }^{24}$ A COVID-19 survey of healthcare workers in Singapore found that $128 / 158(81 \%)$ developed de novo personal protective equipment (PPE)-associated headaches, increasing with duration of use ( $>4$ hours).$^{37}$

One study $(2 \times 2$ factorial design $)$ examined the potential of mask fit test and training to mitigate discomfort but found no clinically or statistically important differences between arms. ${ }^{38}$

Six observational studies reported either general discomfort ${ }^{33}$ or spontaneously reported events among participants who wore face masks. ${ }^{14} 16273540$

\section{Psychological}

Six studies reported on psychological impacts from wearing face masks (four RCTs and two observational).

Fear

A three-arm RCT in a household setting found significantly higher risk perception scores in the mask group
$(38 / 60)$ than non-mask groups $(30 / 60)(\mathrm{p}<0.001)$; participants in the mask group were more fearful that they and their family would get sick from influenza. ${ }^{23} 28$

In an observational study, children in a paediatric emergency department waiting room $(n=80)$ were shown pictures of clinicians wearing either a surgical mask or a clear face shield; 18 children $(22.5 \%)$ reported surgical masks to be more frightening due to an inability to see clinicians' faces, and 14 children $(17.5 \%)$ reported face shields to be more frightening. However, 47 children $(59 \%)$ reported that neither were frightening. ${ }^{25}$

\section{Stigma}

In a two-arm cluster-RCT, 15 (29\%) patients wearing masks reported they did not like being seen wearing a mask. ${ }^{17}$ In a three-arm RCT, more children reported disliking their parents wearing a P2 mask than a surgical mask $(8 / 92$ vs 6/94); however, the difference was not significant. ${ }^{31}$

\section{Loneliness}

One observational study reported on the loneliness outcome. In a survey investigating the psychosocial effects associated with working in a hospital during the

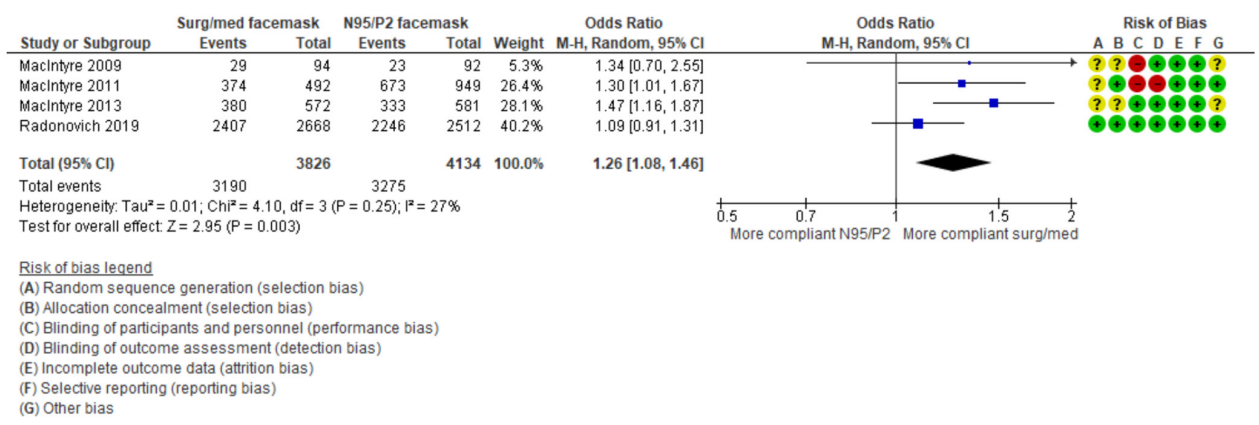

Figure 4 Comparison of adherence to surgical/medical face masks vs N95/P2 masks. 
Table 2 Types of discomfort assessed in trials of face masks used to prevent viral transmission

\begin{tabular}{|c|c|c|c|c|c|}
\hline $\begin{array}{l}\text { First author, year (type of } \\
\text { mask) }\end{array}$ & Population, number & $\begin{array}{l}\text { Difficulty } \\
\text { breathing }\end{array}$ & $\begin{array}{l}\text { Facial irritation } \\
\text { or discomfort }\end{array}$ & Headache & Other \\
\hline $\begin{array}{l}\text { Canini, } 2010^{17} \\
\text { (surgical masks) }\end{array}$ & Household, 105 index cases & $34 \%$ & $14 \%$ & - & $46 \%$ warmth \\
\hline $\begin{array}{l}\text { Chughtai, } 2019^{20} \\
\text { (surgical masks) }\end{array}$ & Healthcare workers, 148 & $12 \%$ & $17 \%$ & $6 \%$ & - \\
\hline $\begin{array}{l}\text { Maclntyre, } 2011^{33} \\
\text { (surgical) }\end{array}$ & Healthcare workers, 492 & $12 \%$ & $11 \%$ & $4 \%$ & - \\
\hline $\begin{array}{l}\text { Maclntyre, } 2011^{33} \\
\text { (N95) }\end{array}$ & Healthcare workers, 949 & $19 \%$ & $52 \%$ & $13 \%$ & - \\
\hline $\begin{array}{l}\text { Maclntyre, } 2015^{32} \\
\text { (cloth vs medical) }\end{array}$ & Healthcare workers, 1130 & $18 \%$ & $35 \%$ & - & - \\
\hline
\end{tabular}

SARS outbreak, $222(13 \%)$ respondents reported a sense of isolation as one reason masks were perceived as bothersome. $^{36}$

\section{Empathy}

One RCT reported that the wearing of a face mask by doctors had a negative effect on patient perceptions of the doctors' empathy during consultations, with a mean Consultation and Relational Empathy score in the mask group of $33.93(\mathrm{SD}=7.65, \mathrm{n}=514)$ and $34.91 \quad(\mathrm{SD}=7.84$, $\mathrm{n}=516)$ in the no mask group $(\mathrm{p}=0.04) .^{50}$

\section{Dyspnoea and other physiological consequences}

Studies of physiological impacts were generally done on masks designed for dust, vapours and other nontransmission purposes; few studied surgical or N95 masks.

A French cross-over study (44 subjects) found surgical masks had no impact on 6 min walking time, but subjects had an increased sense of dyspnoea with a mask: 5.6 versus $4.6 \mathrm{~cm}$ on a $10 \mathrm{~cm}$ visual analogue scale $(\mathrm{p}<0.001),{ }^{39}$ which may come from the increased effort required. A study in 14 adults found that N95 masks increased respiratory resistance in 30 seconds of breathing by over $100 \%$, resulting in average reduction in nasal spirometry of $37 \% .{ }^{29}$ A study of 20 subjects on a treadmill found the surgical masks increased respiratory rate by 1.6 breaths / $\min (\mathrm{p}=0.02)$, heart rate by 9.5 beats $/ \min (\mathrm{p}<0.001)$ and transcutaneous $\mathrm{CO}_{2}$ levels of $2.2 \mathrm{~mm} \mathrm{Hg}(\mathrm{p}<0.001) .{ }^{43}$ Finally, a Chinese study of 15 subjects wearing a monitoring garment for respiratory signals found that N95 masks increased both subjective breathing resistance (from none to mild) and increased respiratory rate; the muscle activity of sternomastoid, scalene, diaphragm and abdominal; and the fatigue of scalene and intercostal. ${ }^{18}$

\section{Communication}

Nine studies (two RCT, seven observational) reported on communication difficulties while wearing face masks.

A trial comparing the use of surgical and N95 masks by healthcare workers to prevent influenza found more workers in the N95 mask group than the surgical mask group reported mask causing trouble with patient communication (8\% vs 3\%). ${ }^{33}$ Another household-based trial of 15 participants who wore a surgical mask for approximately 60 min while performing various tasks 2328 found that participants did not report any interference with communication while answering the phone.

In a cross-over trial of 27 healthcare workers, ${ }^{40}$ more participants in the surgical mask group reported diminished communication acuity (visual, auditory or vocal) as the reason for discontinuing mask use before the end of an 8-hour shift (seven complaints compared with four complaints among N95 mask wearers).

Of 2001 healthcare workers in Toronto responding to a survey during the SARS outbreak, difficulty communicating $(47 \%)$ and difficulty recognising people $(24 \%)$ were identified as key reasons masks (surgical or N95) were perceived as being particularly bothersome. ${ }^{36}$ In a survey of 149 healthcare workers, ${ }^{14} 41$ (27.5\%) of respondents reported a difficulty 'always' / 'most of time' in verbally communicating with patients while wearing a mask.

In another Canadian survey (115 healthcare workers) ${ }^{35}$ $26(23 \%)$ respondents reported that wearing masks interfered with their relationships with their patients. Among 148 healthcare workers asked to wear a mask during a 6-8 hour shift, $11(7.4 \%)$ reported trouble communicating with patients. $^{20}$

In a study of three participants evaluating the impact of wearing a surgical or N95 mask on radio reception, all participants were able to accurately record all pilotrecited words regardless of the type of mask worn by the pilot. However, when the aircraft engine was turned on, the accuracy decreased for the N95 mask, compared with surgical or no mask. ${ }^{48}$

In another lab-based study, the performance or absence of fit testing prior to mask use did not affect communication, as two participants (out of 21) in each group reported ease of talking to be unsatisfactory. ${ }^{38}$

\section{Mask contamination and other issues}

One concern about mask use is the potential for contamination of the mask surface and subsequent self-inoculation to the wearer's eyes or when demasking. No studies examined that directly, but one study of the healthcare workers 
found on average $10 \%$ of masks had viral contamination after usage and that was higher for masks worn $>6$ hours (OR 7.9, 95\% CI 1.01 to 61.99 ) or $>25$ patients seen (OR $5.02,95 \%$ CI 1.35 to 18.60$).{ }^{20}$ Given the rates of misuse (see Misuse section above), this contamination raises concerns about self-inoculation.

Several authors have raised concerns about 'risk compensation'-non-adherence to other precautions because of the sense of protection-but we found no studies that quantify its extent.

\section{DISCUSSION}

We identified 37 studies reporting downsides, harms and adverse events associated with the wearing of face masks: 15 RCTs and 22 observational studies. The largest number of studies reported on the discomfort and irritation outcome (20 studies), fewest on misuse of mask (four studies), with no studies directly investigating or quantifying mask contamination or risk compensation behaviour. The only meta-analysable outcome was adherence to face mask wear (17 studies, 11 meta-analysed). Forty-seven per cent more people wore face masks in the face mask group compared with control, although the percentage of people wearing face masks in the control group was non-zero in five studies; face mask wear adherence was also significantly higher (26\%) in the surgical/medical mask group than the N95/P2 group. Risk of bias was generally high for blinding of participants and personnel, and selection bias, and low for attrition and reporting biases.

This is the first systematic review to investigate the downsides of wearing face masks and forms an important step as a bridge between research and action. The review aligns with the aims of the behavioural, environmental, social and systems interventions collaboration (BESSI) and addresses important evidence gaps in the appropriate use of face masks. The review's strength lies in its inclusion of non-randomised study designs in addition to RCTs, as trials frequently under-report or fail to report harms. ${ }^{52}$ Additionally, the inclusion and exclusion criteria were tested and refined on a test library of 98 references, prior to screening the full search results. The key limitation includes the hospital setting of most of the included studies: as hospital workers are accustomed to wearing masks, the conclusions may not be fully generalisable to the community. Although this varies among the studies that reported mask use in hospital setting, as there are different confounding factors that may contribute to increased reporting of irritation (eg, length of shift, air-conditioning on the wards and whether the staff were wearing the full PPE, which adds to the full discomfort). We report two differences between the protocol and the review: first, the comparison of face mask to control in the adherence outcome was reported using RD (rather than preplanned OR) to more clearly convey the differences between the two groups (OR for compliance with face mask wear was reported for the face mask vs face mask comparison, however). Second, not having anticipated data availability, we did not prespecify a subgroup analysis of the intervention (face mask wearing) by studies that evaluated face mask wear alone and studies evaluating face mask with hand washing. Potential behavioural or cultural bias may have been introduced into the findings due to some cultural groups already being more accustomed to wearing face masks when coughing or sick. However, among our included studies, only four were conducted in the community in Asian countries, and of these studies, three reported adherence to face mask use as an issue and one study reported that 264 out of the 624 of the participants who have failed N95 fit test have used masks previously. Furthermore, the use of face masks/coverings in the various study settings compared with their use in a real-life pandemic may differ from a behavioural perspective, and this may affect findings related to adherence. However, other reported harms, such as physiological changes, may be less affected by the differences in circumstance.

Several recent systematic reviews have focused on the effectiveness of masks in preventing or reducing viral transmission; some of these reviews reported on harms in the included studies. ${ }^{8184253}$ However, none specifically focused on the wider set of studies examining the physiological, psychological and other adverse effects addressed in this review. The Cochrane review on physical barriers noted the impact of masks on discomfort and communication in some of the randomised trials, and its findings are consistent with this review but did not extend to studies with outcomes other than viral transmission or non-randomised study design. ${ }^{3}$

The downsides identified in this review should aid in designing strategies to mitigate problems and guide the situations where the benefits of masks might outweigh the downsides. Patient preferences for surgical masks (as indicated by the higher adherence than to the N95 masks), would suggests that the mitigation of discomforts may also increase adherence to face mask wear, and hence their effectiveness, whether for preventing transmission of the virus by the wearer (eg, surgical masks) or for preventing inhalation of viral particles in the environment (eg, N95 masks). Mitigation might be achieved by considering of the when, where and how of mask wearing (including the fitting process required for some masks like FFP and N95) as the choice of alternative would be dependent on the specific context; that is, it may not be appropriate to use surgical masks or other face masks interchangeably with respirator masks in situations where the goal is to prevent inhalation of aerosolised viral particles as they are not designed for that purpose unlike respirator masks or by mask redesign or substitution with alternatives (eg, face shields).

Potential mitigation strategies

Limiting circumstances: use of face masks should be restricted to higher risk circumstances, including 
crowded, indoor spaces, where physical distancing is not possible, for example, public transport. This recommendation corresponds with suggestions by Chu et al, who reported that optimum face mask use in public settings could result in a large reduction in infection. ${ }^{5}$ Conversely, exercising outdoors is both low risk and has higher downside of wearing masks, because of the increased perceived dyspnoea.

Limiting duration of face mask wear: duration increases both discomfort and non-adherence. Duration might be decreased by demasking during breaks or scheduling mask breaks. Changing masks more often will help with adherence and the contamination risks but will increase costs and environmental problems with waste disposal, as well as lead to potential contamination/transmission risks if not performed appropriately.

Modification for specific groups: some groups are likely to have greater difficulty with mask wearing adherence and correct usage, including children, some patients with mental illnesses, those with cognitive impairment or respiratory disorders such as asthma or chronic airways disease and patients with recent facial trauma or oromaxillofacial surgery. ${ }^{54-56}$

Substitution: face shields may provide an alternative to face masks, which may mitigate several of the downsides (eg, reducing the communication difficulties and breathing resistance), while also providing eye protection. However, there is little evidence on the discomforts of wearing face shields and on the degree of protection provided, as airborne particles could escape through the upward and downwards jet. ${ }^{57} 58$ Other innovative mask designs currently being developed require discomfort and adherence evaluations in addition to the droplet penetration.

Currently, existing research does not allow firm conclusions as there are insufficient data to quantify all of the adverse effects that might reduce the acceptability, adherence and effectiveness of face masks. Any new research on face masks should assess and report the harms and downsides, including behavioural issues (ie, risk compensation behaviour) and the psychological impact of mandated face mask wear. There is an urgent need for priority funding for high-quality research on methods and designs to mitigate downsides of face mask wearing, particularly the assessment of possible alternatives.

\section{Twitter Mina Bakhit @Mina_Bakhit}

Acknowledgements Our thanks to Tom Jefferson for stimulating this review and providing comments and to John Conly and Marylouise McClaws for comments on the draft.

Contributors CDM and PG conceived the study. MB, AMS, NK, PG and CDM drafted the protocol. JC designed the search strategy and performed the literature search. MB, NK, AMS and JC screened studies for eligibility and assessed the risk of bias. All authors performed data extraction. AMS performed the meta-analysis. MB, NK, AMS, PG and CDM performed the narrative analysis for non-meta-analysed studies. All authors critically reviewed the manuscript, contributed to its revision and approved the final version submitted. The corresponding author confirms that all listed authors meet authorship criteria and that no others meeting the criteria have been omitted. CDM is the guarantor.
Funding The present systematic review was conducted as part of the work of the Centre of Research Excellence in Minimising Antibiotic Resistance in the Community, funded by the National Health and Medical Research Council, Australia (grant reference number: GNT1153299).

Competing interests None declared.

Patient consent for publication Not required.

Provenance and peer review Not commissioned; externally peer reviewed.

Data availability statement All data relevant to the study are included in the article or uploaded as supplementary information.

Supplemental material This content has been supplied by the author(s). It has not been vetted by BMJ Publishing Group Limited (BMJ) and may not have been peer-reviewed. Any opinions or recommendations discussed are solely those of the author(s) and are not endorsed by BMJ. BMJ disclaims all liability and responsibility arising from any reliance placed on the content. Where the content includes any translated material, BMJ does not warrant the accuracy and reliability of the translations (including but not limited to local regulations, clinical guidelines, terminology, drug names and drug dosages), and is not responsible for any error and/or omissions arising from translation and adaptation or otherwise.

Open access This is an open access article distributed in accordance with the Creative Commons Attribution Non Commercial (CC BY-NC 4.0) license, which permits others to distribute, remix, adapt, build upon this work non-commercially, and license their derivative works on different terms, provided the original work is properly cited, appropriate credit is given, any changes made indicated, and the use is non-commercial. See: http://creativecommons.org/licenses/by-nc/4.0/.

\section{ORCID iDs}

Mina Bakhit http://orcid.org/0000-0002-6162-3362

Natalia Krzyzaniak http://orcid.org/0000-0001-5668-7292

Anna Mae Scott http://orcid.org/0000-0002-0109-9001

Paul Glasziou http://orcid.org/0000-0001-7564-073X

\section{REFERENCES}

1 Tellier R, Li Y, Cowling BJ, et al. Recognition of aerosol transmission of infectious agents: a commentary. BMC Infect Dis 2019;19:101.

2 Bartoszko JJ, Faroogi MAM, Alhazzani W, et al. Medical masks vs N95 respirators for preventing COVID-19 in healthcare workers: a systematic review and meta-analysis of randomized trials. Influenza Other Respir Viruses 2020;14:365-73.

3 Jefferson T, Jones M, Al Ansari LA. Physical interventions to interrupt or reduce the spread of respiratory viruses. Part 1 - Face masks, eye protection and person distancing: systematic review and metaanalysis. medRxiv2020:2020.03.30.20047217.

4 Offeddu V, Yung CF, Low MSF, et al. Effectiveness of masks and respirators against respiratory infections in healthcare workers: a systematic review and meta-analysis. Clin Infect Dis 2017;65:1934-42.

5 Chu DK, Akl EA, Duda S, et al. Physical distancing, face masks, and eye protection to prevent person-to-person transmission of SARS-CoV-2 and COVID-19: a systematic review and meta-analysis. Lancet 2020;395:1973-87.

6 Greenhalgh T. Face coverings for the public: laying straw men to rest. $J$ Eval Clin Pract 2020;26:1070-7.

$7 \mathrm{Sim}$ SW, Moey KSP, Tan NC. The use of facemasks to prevent respiratory infection: a literature review in the context of the health belief model. Singapore Med J 2014;55:160-7.

8 Moher D, Liberati A, Tetzlaff J, et al. Preferred reporting items for systematic reviews and meta-analyses: the PRISMA statement. PLOS Med 2009;6:e1000097.

9 Clark J, Glasziou P, Del Mar C, et al. A full systematic review was completed in 2 weeks using automation tools: a case study. J Clin Epidemiol 2020;121:81-90.

10 Clark JM, Sanders S, Carter M, et al. Improving the translation of search strategies using the Polyglot search Translator: a randomized controlled trial. J Med Libr Assoc 2020;108:195-207.

11 Higgins J, Deeks J, Altman D. Special topics in statistics. In: Higgins JPT, Green S, eds. Cochrane Handbook for systematic reviews of interventions version 5.1. 0 (updated March 2011. The Cochrane Collaboration, 2011.

12 Aiello AE, Perez V, Coulborn RM, et al. Facemasks, hand hygiene, and influenza among young adults: a randomized intervention trial. PLoS One 2012;7:e29744. 
13 Allison MA, Guest-Warnick G, Nelson D, et al. Feasibility of elementary school children's use of hand gel and facemasks during influenza season. Influenza Other Respir Viruses 2010;4:223-9.

14 Baig AS, Knapp C, Eagan AE, et al. Health care workers' views about respirator use and features that should be included in the next generation of respirators. Am J Infect Control 2010;38:18-25.

15 Barasheed O, Almasri N, Badahdah A-M, et al. Pilot randomised controlled trial to test effectiveness of Facemasks in preventing influenza-like illness transmission among Australian hajj pilgrims in 2011. Infect Disord Drug Targets 2014;14:110-6.

16 Bryce E, Forrester L, Scharf S, et al. What do healthcare workers think? A survey of facial protection equipment user preferences. $J$ Hosp Infect 2008;68:241-7.

17 Canini L, Andréoletti L, Ferrari P, et al. Surgical mask to prevent influenza transmission in households: a cluster randomized trial. PLoS One 2010;5:e13998.

18 Chen Y, Yang Z, Wang J, et al. Physiological and subjective responses to breathing resistance of N95 filtering facepiece respirators in still-sitting and walking. Int $J$ Ind Ergon 2016;53:93-101.

19 Chughtai AA, Seale H, Dung TC, et al. Compliance with the use of medical and cloth masks among healthcare workers in Vietnam. Ann Occup Hyg 2016;60:619-30.

20 Chughtai AA, Stelzer-Braid S, Rawlinson W, et al. Contamination by respiratory viruses on outer surface of medical masks used by hospital healthcare workers. BMC Infect Dis 2019;19:491.

21 Cowling BJ, Chan K-H, Fang VJ, et al. Facemasks and hand hygiene to prevent influenza transmission in households: a cluster randomized trial. Ann Intern Med 2009;151:437-46.

22 Cowling BJ, Fung ROP, Cheng CKY, et al. Preliminary findings of a randomized trial of non-pharmaceutical interventions to prevent influenza transmission in households. PLoS One 2008;3:e2101.

23 Ferng Y-hui, Wong-McLoughlin J, Barrett A, et al. Barriers to mask wearing for influenza-like illnesses among urban Hispanic households. Public Health Nurs 2011;28:13-23.

$24 \mathrm{Foo} \mathrm{CCl}$, Goon ATJ, Leow Y-H, et al. Adverse skin reactions to personal protective equipment against severe acute respiratory syndrome--a descriptive study in Singapore. Contact Dermatitis 2006;55:291-4.

25 Forgie SE, Reitsma J, Spady D, et al. The "fear factor" for surgical masks and face shields, as perceived by children and their parents. Pediatrics 2009;124:e777-81.

26 Jacobs JL, Ohde S, Takahashi O, et al. Use of surgical face masks to reduce the incidence of the common cold among health care workers in Japan: a randomized controlled trial. Am J Infect Control 2009;37:417-9.

27 Kao T-W, Huang K-C, Huang Y-L, et al. The physiological impact of wearing an N95 mask during hemodialysis as a precaution against SARS in patients with end-stage renal disease. J Formos Med Assoc 2004;103:624-8.

28 Larson EL, Ferng Y-hui, Wong-McLoughlin J, et al. Impact of nonpharmaceutical interventions on URIs and influenza in crowded, urban households. Public Health Rep 2010;125:178-91.

29 Lee HP, Wang DY. Objective assessment of increase in breathing resistance of N95 respirators on human subjects. Ann Occup Hyg 2011;55:917-21.

30 Lim ECH, Seet RCS, Lee K-H, et al. Headaches and the N95 face-mask amongst healthcare providers. Acta Neurol Scand 2006;113:199-202.

31 Maclntyre CR, Cauchemez S, Dwyer DE, et al. Face mask use and control of respiratory virus transmission in households. Emerg Infect Dis 2009;15:233-41.

32 Maclntyre CR, Seale H, Dung TC, et al. A cluster randomised trial of cloth masks compared with medical masks in healthcare workers. BMJ Open 2015;5:e006577.

33 Maclntyre CR, Wang Q, Cauchemez S, et al. A cluster randomized clinical trial comparing fit-tested and non-fit-tested N95 respirators to medical masks to prevent respiratory virus infection in health care workers. Influenza Other Respir Viruses 2011;5:170-9.

34 Maclntyre $\mathrm{CR}$, Wang $\mathrm{Q}$, Seale $\mathrm{H}$, et al. A randomized clinical trial of three options for N95 respirators and medical masks in health workers. Am J Respir Crit Care Med 2013;187:960-6.
35 Martel J, Bui-Xuan E-F, Carreau A-M, et al. Respiratory hygiene in emergency departments: compliance, beliefs, and perceptions. Am J Infect Control 2013;41:14-18.

36 Nickell LA, Crighton EJ, Tracy CS, et al. Psychosocial effects of SARS on hospital staff: survey of a large tertiary care institution. CMAJ 2004;170:793-8.

37 Ong JJY, Bharatendu C, Goh Y, et al. Headaches Associated With Personal Protective Equipment - A Cross-Sectional Study Among Frontline Healthcare Workers During COVID-19. Headache 2020;60:864-77.

38 Or PP, Chung JW, Wong TK. A study of environmental factors affecting nurses' comfort and protection in wearing N95 respirators during bedside procedures. J Clin Nurs 2018;27:e1477-84.

39 Person E, Lemercier C, Royer A, et al. [Effect of a surgical mask on six minute walking distance]. Rev Mal Respir 2018;35:264-8.

40 Radonovich LJ, Cheng J, Shenal BV, et al. Respirator tolerance in health care workers. JAMA 2009;301:36-8.

41 Radonovich LJ, Simberkoff MS, Bessesen MT, et al. N95 respirators vs medical masks for preventing influenza among health care personnel: a randomized clinical trial. JAMA 2019;322:824-33.

42 Rebmann T, Carrico R, Wang J. Physiologic and other effects and compliance with long-term respirator use among medical intensive care unit nurses. Am J Infect Control 2013;41:1218-23.

43 Roberge RJ, Kim J-H, Benson SM. Absence of consequential changes in physiological, thermal and subjective responses from wearing a surgical mask. Respir Physiol Neurobiol 2012;181:29-35.

44 Shenal BV, Radonovich LJ, Cheng J, et al. Discomfort and exertion associated with prolonged wear of respiratory protection in a health care setting. J Occup Environ Hyg 2012;9:59-64.

45 Simmerman JM, Suntarattiwong P, Levy J, et al. Findings from a household randomized controlled trial of hand washing and face masks to reduce influenza transmission in Bangkok, Thailand. Influenza Other Respir Viruses 2011;5:256-67.

46 Suess T, Remschmidt C, Schink S, et al. Facemasks and intensified hand hygiene in a German household trial during the 2009/2010 influenza $\mathrm{A}(\mathrm{H} 1 \mathrm{~N} 1)$ pandemic: adherence and tolerability in children and adults. Epidemiol Infect 2011;139:1895-901.

47 Suess T, Remschmidt C, Schink SB, et al. The role of facemasks and hand hygiene in the prevention of influenza transmission in households: results from a cluster randomised trial; Berlin, Germany, 2009-2011. BMC Infect Dis 2012;12:26.

48 Thomas F, Allen C, Butts W, et al. Does wearing a surgical facemask or N95-respirator impair radio communication? Air Med J 2011;30:97-102.

49 Vanjak D, Delaporte MF, Bonmarin I, et al. [Cases of pertussis among healthcare workers in a maternity ward: management of a health alert]. Med Mal Infect 2006;36:151-6.

50 Wong CKM, Yip BHK, Mercer S, et al. Effect of facemasks on empathy and relational continuity: a randomised controlled trial in primary care. BMC Fam Pract 2013;14:200.

51 Yeung W, $\mathrm{Ng} \mathrm{K}$, Fong JMN, et al. Assessment of proficiency of N95 mask Donning among the general public in Singapore. JAMA Netw Open 2020;3:e209670-e70.

52 Vandenbroucke JP. When are observational studies as credible as randomised trials? Lancet 2004;363:1728-31.

53 Perski O, Simons D, West R, et al. Face masks to prevent community transmission of viral respiratory infections: a rapid evidence review using Bayesian analysis. Qeios 2020.

54 Kyung SY, Kim Y, Hwang $\mathrm{H}$, et al. Risks of N95 face mask use in subjects with COPD. Respir Care 2020;65:658-64.

55 DementiaUK. Advice for people with dementia around face coverings, 2020. Available: https://www.dementiauk.org/adviceabout-face-coverings/ [Accessed 22 Sep 2020].

56 Seale H. It's easy to judge. But some people really can't wear a mask: The Conversation, 2020. Available: https://theconversation. com/its-easy-to-judge-but-some-people-really-cant-wear-a-mask143258 [Accessed 22 Sep 2020].

57 Czypionka T, Greenhalgh T, Bassler D, et al. Masks and Face Coverings for the Lay Public : A Narrative Update. Ann Intern Med 2020. doi:10.7326/M20-6625. [Epub ahead of print: 29 Dec 2020].

58 Howard J, Huang A, Li Z, et al. An evidence review of face masks against COVID-19. Proc Natl Acad Sci U S A 2021;118:e2014564118. 
Appendix 1. Summary of the different types of facemasks included in the review and their intended uses

\begin{tabular}{|c|c|}
\hline $\begin{array}{l}\text { Type of face } \\
\text { mask/covering }\end{array}$ & Description and Intended use \\
\hline Surgical mask ${ }^{1,2}$ & $\begin{array}{l}\text { - Loose-fitting, disposable device, made in different thicknesses } \\
\text { - Creates a physical, protective barrier between the mouth and nose of } \\
\text { the wearer and potential contaminants in the immediate environment } \\
\text { i.e. splashes, sprays, large droplets or splatter. } \\
\text { - } \quad \text { Primarily intended to prevent the wearer from spreading respiratory } \\
\text { droplets } \\
\text { - Intended for single use } \\
\text { - Does not filter or block very small particles, gases or chemicals in the air } \\
\text { that may be transmitted by coughs, sneezes, or certain medical } \\
\text { procedures. } \\
\text { Do not provide complete protection from germs and other } \\
\text { contaminants because of the loose fit between the surface of the mask } \\
\text { and the face. }\end{array}$ \\
\hline N95 mask ${ }^{2,3}$ & $\begin{array}{l}\text { - } \quad \text { Respiratory protective device designed to achieve a very close facial fit. } \\
\text { The edges of the respirator are designed to form a seal around the nose } \\
\text { and mouth. } \\
\text { - } \quad \text { Require fit-testing and must be adjusted to the face. } \\
\text { - } \quad \text { Intended to help reduce wearer exposure to airborne particles as well } \\
\text { as larger droplets and protect the wearer from splashes and sprays. } \\
\text { - } \quad \text { Filters out very fine particles. } \\
\text { - } \quad \text { Commonly used in healthcare settings. } \\
\text { - } \quad \text { Should not be shared or reused. }\end{array}$ \\
\hline $\begin{array}{l}\text { Non-medical face } \\
\text { masks/covering }\end{array}$ & $\begin{array}{l}\text { - Cloth face coverings are only intended to help contain the wearer's } \\
\text { respiratory droplets from being spread. } \\
\text { - } \quad \text { At least 2-3 layers needed to block respiratory droplets. } \\
\text { - } \quad \text { Not intended for use in a clinical setting or explicitly to prevent the } \\
\text { transmission of disease between persons. } \\
\text { - } \quad \text { Some are reusable, and need to be washed after each use. }\end{array}$ \\
\hline
\end{tabular}

1. U.S. Food and Drugs Administration (2012). "510(K) Summary ". Retrieved 17/09/20, from https://www.accessdata.fda.gov/cdrh_docs/pdf12/K122717.pdf.

2. U.S. Food and Drug Administration (2020). "N95 Respirators, Surgical Masks, and Face Masks." Retrieved 17/09/20, from https://www.fda.gov/medical-devices/personal-protective-equipment-infection-control/n95respirators-surgical-masks-and-face-masks.

3. N95) Victoria State Government (2020). Coronavirus (COVID-19) - PPE and levels of protection. Department of Health and Human Services.

4. U.S. Food and Drug Administration (2020). "Use of Respirators, Facemasks, and Cloth Face Coverings in the Food and Agriculture Sector During Coronavirus Disease (COVID-19) Pandemic." Retrieved 17/09/20, from https://www.fda.gov/food/food-safety-during-emergencies/use-respirators-facemasks-and-cloth-face-coveringsfood-and-agriculture-sector-duringcoronavirus\#: :text=Cloth\%20face\%20coverings\%20are\%20only,from\%20spreading\%20it\%20to\%20others. 
Appendix 2. List of excluded face masks

- Oxygen face masks

- OxyMask

- Goldman nasal masks

- Patil-Syracuse Mask

- Ventilation masks

- non-invasive ventilation masks

- Venti-Mask

- Venturi mask

- Mechanical ventilation masks

- Facemask anaesthesia (Anaesthesia induction using face masks)

- Sports protective masks (Hockey masks)

- Diving masks, Scuba masks

- Thermoplastic masks (protective masks for irradiation fields and radiotherapy)

- Bag-valve-mask

- Laryngeal mask

- Oronasal masks

- Sleep masks

- N95 masks with valves (as it does not reduce the spread of virus transmission) 


\section{Appendix 3. Database search strings}

Searches conducted 18 May 2020:

PubMed

(("Masks/adverse effects"[MAJR])

OR

((Masks[Mesh] OR "Respiratory protective devices"[Mesh] OR Facemask[tiab] OR Facemasks[tiab] OR Mask[tiab] OR Masks[tiab] OR Faceshield[tiab] OR Faceshields[tiab] OR Goggles[tiab] OR “Face shield"[tiab] OR “Face shields"[tiab] OR Visors[tiab] OR “Face covering"[tiab])

AND

("Adverse effects"[sh] OR "Adverse effect"[tiab] OR “Adverse effects"[tiab] OR “Adversely affect"[tiab] OR “Adverse event"[tiab] OR “Adverse events"[tiab] OR Discomfort[tiab] OR Fatigue[tiab] OR Pain[tiab] OR “Difficulty breathing"[tiab] OR “Breathing difficulty"[tiab] OR "Shortness of breath"[tiab] OR "Risk compensation"[tiab] OR Fomite[tiab] OR Fomites[tiab] OR Dislike[tiab] OR "Physiological impacts"[tiab] OR “Physiological impact"[tiab] OR Sweating[tiab] OR Irritation[tiab] OR “Psychological reactions"[tiab] OR Fear[tiab] OR Communication[tiab] OR “Deaf persons" [tiab] OR Lip-reading[tiab] OR “Lip reading”[tiab] OR Vitiligo[tiab] OR Humidity[tiab] OR "Face dermatitis"[tiab] OR Acne[tiab] OR Redness[tiab] OR Ulcer[tiab] OR "Speech understanding" [tiab] OR "Pinching of skin" [tiab] OR “Moisture buildup" [tiab] OR "Facial warmth"[tiab])

AND

(Relieve[tiab] OR Attitudes[tiab] OR Induced[tiab] OR Modified[tiab] OR Decreased[tiab] OR Decrease[tiab] OR Associated[tiab] OR Impair[tiab] OR Reduce[tiab] OR Reducing[tiab] OR Reduced[tiab] OR Duration[tiab])

AND

("randomized controlled trial" [pt] OR "controlled clinical trial" [pt] OR randomized[tiab] OR randomised[tiab] OR placebo[tiab] OR randomly[tiab] OR trial[tiab] OR groups[tiab] OR "Epidemiologic Studies"[Mesh] OR “case-control studies"[Mesh] OR “Cohort Studies"[Mesh] OR "case control"[tiab] OR Cohort[tiab] OR “Follow up"[tiab] OR Observational[tiab] OR Longitudinal[tiab] OR Prospective[tiab] OR Retrospective[tiab] OR "cross sectional" [tiab] OR “CrossSectional Studies"[Mesh] OR Evaluated[tiab] OR Impact[tiab] OR Analysis[tiab] OR Statistics[tiab] OR Data[tiab] OR "statistics and numerical data"[sh] OR "epidemiology"[sh] OR Etiology[sh] OR Effect[tiab] OR Effects[tiab] OR Affect[tiab])))

NOT

("Continuous Positive Airway Pressure"[Mesh] OR "Positive Airway Pressure"[tiab] OR CPAP[tiab] OR "Laryngeal Masks"[Mesh] OR "Intubation, Intratracheal"[Mesh] OR “Oxygen masks”[tiab] OR 
“Oxygen mask"[tiab] OR OxyMask[tiab] OR “Nasal masks"[tiab] OR “Patil-Syracuse Mask"[tiab] OR "Ventilation masks"[tiab] OR "Venti-Mask"[tiab] OR “Venturi mask"[tiab] OR “Diving masks"[tiab] OR “Thermoplastic masks"[tiab] OR Bag-valve-mask[tiab] OR “Laryngeal mask"[tiab] OR "Laryngeal masks" [tiab] OR “Oronasal masks" [tiab] OR “Sleep mask”[tiab] OR Editorial[pt] OR Letter[pt] OR "Case reports"[pt])

NOT

(Animals[Mesh] not (Animals[Mesh] and Humans[Mesh]))

OR

(Masks[Mesh] OR "Respiratory protective devices"[Mesh] OR Facemask[tiab] OR Facemasks[tiab] OR Mask[tiab] OR Masks[tiab] OR Faceshield[tiab] OR Faceshields[tiab] OR Goggles[tiab] OR “Face shield”[tiab] OR “Face shields"[tiab] OR Visors[tiab] OR “Face covering"[tiab])

AND

("Respiratory Tract Infections"[Mesh] OR Influenza[tiab] OR "Respiratory Tract Diseases"[Mesh] OR Influenzas[tiab] OR "Influenza-like"[tiab] OR ILI[tiab] OR "common cold"[tiab] OR colds[tiab] OR coryza[tiab] OR coronavirus[Mesh] OR "sars virus"[Mesh] OR coronavirus[tiab] OR Coronaviruses[tiab] OR "coronavirus infections"[Mesh] OR "severe acute respiratory syndrome"[Mesh] OR "severe acute respiratory syndrome"[tiab] OR "severe acute respiratory syndromes"[tiab] OR sars[tiab] OR "respiratory syncytial viruses"[Mesh] OR "respiratory syncytial virus, human"[Mesh] OR "Respiratory Syncytial Virus Infections"[Mesh] OR "respiratory syncytial virus"[tiab] OR "respiratory syncytial viruses"[tiab] OR rsv[tiab] OR parainfluenza[tiab] OR “Respiratory illness"[tiab] OR ((Transmission[tiab]) AND (Coughing[tiab] OR Sneezing[tiab])) OR ((respiratory[tiab] AND Tract[tiab]) AND (infection[tiab] OR Infections[tiab] OR illness[tiab])) OR "Communicable Disease Control"[Mesh] OR "Disease Outbreaks"[Mesh] OR "Disease Transmission, Infectious"[Mesh] OR "Infection Control"[Mesh] OR Transmission[sh] OR "Communicable Disease Control"[tiab] OR "Secondary transmission"[tiab] OR ((Reduced[tiab] OR Reduce[tiab] OR Reduction[tiab] OR Reducing[tiab] OR Lower[tiab]) AND (Incidence[tiab] OR Occurrence[tiab] OR Transmission[tiab] OR Secondary[tiab])) OR Physiological[tiab])

AND

("Adverse effects"[sh] OR “Adverse effect"[tiab] OR “Adverse effects"[tiab] OR “Adverse event"[tiab] OR “Adverse events"[tiab] OR “Index cases"[tiab] OR “Attack rates"[tiab] OR ((Reduce[tiab] OR Reduction[tiab]) AND (Rate[tiab] OR Rates[tiab])) OR Perception[tiab] OR Prevent[tiab] OR Adherence[tiab])

AND

("randomized controlled trial" [pt] OR "controlled clinical trial”[pt] OR randomized[tiab] OR randomised[tiab] OR placebo[tiab] OR randomly[tiab] OR trial[tiab] OR groups[tiab] OR "Epidemiologic Studies"[Mesh] OR “case-control studies"[Mesh] OR “Cohort Studies”[Mesh] OR "case control"[tiab] OR Cohort[tiab] OR “Follow up"[tiab] OR Observational[tiab] OR Longitudinal[tiab] OR Prospective[tiab] OR retrospective[tiab] OR “cross sectional”[tiab] OR “Cross- 
Sectional Studies"[Mesh] OR Evaluated[tiab] OR Impact[tiab] OR Analysis[tiab] OR Statistics[tiab] OR Data[tiab] OR "statistics and numerical data"[sh] OR "epidemiology"[sh])

NOT

("Continuous Positive Airway Pressure"[Mesh] OR "Positive Airway Pressure"[tiab] OR CPAP[tiab] OR "Laryngeal Masks"[Mesh] OR "Intubation, Intratracheal"[Mesh] OR “Oxygen masks"[tiab] OR “Oxygen mask"[tiab] OR OxyMask[tiab] OR “Goldman nasal masks”[tiab] OR “Patil-Syracuse Mask"[tiab] OR “Ventilation masks"[tiab] OR "Venti-Mask"[tiab] OR "Venturi mask" [tiab] OR “Hockey mask"[tiab] OR “Diving masks"[tiab] OR "Thermoplastic masks"[tiab] OR Bag-valvemask[tiab] OR "Laryngeal mask"[tiab] OR “Laryngeal masks"[tiab] OR “Oronasal masks"[tiab] OR "Sleep mask"[tiab] OR "Case Reports"[pt])

NOT

(Animals[Mesh] not (Animals[Mesh] and Humans[Mesh]))

\section{Cochrane CENTRAL}

(([mh Masks/AE])

OR

(([mh Masks] OR [mh "Respiratory protective devices"] OR Facemask:ti,ab OR Facemasks:ti,ab OR Mask:ti,ab OR Masks:ti,ab OR Faceshield:ti,ab OR Faceshields:ti,ab OR Goggles:ti,ab OR "Face shield":ti,ab OR "Face shields":ti,ab OR Visors:ti,ab OR "Face covering":ti,ab)

AND

("Adverse effect":ti,ab OR "Adverse effects":ti,ab OR "Adversely affect":ti,ab OR "Adverse event":ti,ab OR "Adverse events":ti,ab OR Discomfort:ti,ab OR Fatigue:ti,ab OR Pain:ti,ab OR "Difficulty breathing":ti,ab OR "Breathing difficulty":ti,ab OR "Shortness of breath":ti,ab OR "Risk compensation":ti,ab OR Fomite:ti,ab OR Fomites:ti,ab OR Dislike:ti,ab OR "Physiological impacts":ti,ab OR "Physiological impact":ti,ab OR Sweating:ti,ab OR Irritation:ti,ab OR "Psychological reactions":ti,ab OR Fear:ti,ab OR Communication:ti,ab OR "Deaf persons":ti,ab OR "Lip reading":ti,ab OR Vitiligo:ti,ab OR Humidity:ti,ab OR "Glasses misting" OR "Face dermatitis":ti,ab OR Acne:ti,ab OR Redness:ti,ab OR Ulcer:ti,ab OR "Speech understanding":ti,ab OR "Pinching of skin":ti,ab OR "Moisture buildup":ti,ab OR "Facial warmth":ti,ab)

AND

(Relieve:ti,ab OR Attitudes:ti,ab OR Induced:ti,ab OR Modified:ti,ab OR Decreased:ti,ab OR Decrease:ti,ab OR Associated:ti,ab OR Impair:ti,ab OR Reduce:ti,ab OR Reducing:ti,ab OR Reduced:ti,ab OR Duration:ti,ab)))

NOT 
([mh "Continuous Positive Airway Pressure"] OR "Positive Airway Pressure":ti,ab OR CPAP:ti,ab OR [mh "Laryngeal Masks"] OR [mh "Intubation, Intratracheal"] OR "Oxygen masks":ti,ab OR "Oxygen mask":ti,ab OR OxyMask:ti,ab OR "Nasal masks":ti,ab OR "Patil Syracuse Mask":ti,ab OR "Ventilation masks":ti,ab OR “Venti Mask":ti,ab OR "Venturi mask":ti,ab OR "Hockey mask":ti,ab OR "Diving masks":ti,ab OR "Thermoplastic masks":ti,ab OR "Bag valve mask":ti,ab OR "Laryngeal mask":ti,ab OR "Laryngeal masks":ti,ab OR "Oronasal masks":ti,ab OR "Sleep mask":ti,ab)

OR

([mh Masks] OR [mh "Respiratory protective devices"] OR Facemask:ti,ab OR Facemasks:ti,ab OR Mask:ti,ab OR Masks:ti,ab OR Faceshield:ti,ab OR Faceshields:ti,ab OR Goggles:ti,ab OR "Face shield":ti,ab OR "Face shields":ti,ab OR Visors:ti,ab OR "Face covering":ti,ab)

AND

([mh "Respiratory Tract Infections"] OR Influenza:ti,ab OR [mh "Respiratory Tract Diseases"] OR Influenzas:ti,ab OR ILI:ti,ab OR "common cold":ti,ab OR colds:ti,ab OR coryza:ti,ab OR [mh coronavirus] OR [mh "sars virus"] OR coronavirus:ti,ab OR Coronaviruses:ti,ab OR [mh "coronavirus infections"] OR [mh "severe acute respiratory syndrome"] OR "severe acute respiratory syndrome":ti,ab OR "severe acute respiratory syndromes":ti,ab OR sars:ti,ab OR [mh "respiratory syncytial viruses"] OR [mh "respiratory syncytial virus, human"] OR [mh "Respiratory Syncytial Virus Infections"] OR "respiratory syncytial virus":ti,ab OR "respiratory syncytial viruses":ti,ab OR rsv:ti,ab OR parainfluenza:ti,ab OR "Respiratory illness":ti,ab OR ((Transmission:ti,ab) AND (Coughing:ti,ab OR Sneezing:ti,ab)) OR ((respiratory:ti,ab AND Tract:ti,ab) AND (infection:ti,ab OR Infections:ti,ab OR illness:ti,ab)) OR [mh "Communicable Disease Control"] OR [mh "Disease Outbreaks"] OR [mh "Disease Transmission, Infectious"] OR [mh "Infection Control"] OR "Communicable Disease Control":ti,ab OR "Secondary transmission":ti,ab OR ((Reduced:ti,ab OR Reduce:ti,ab OR Reduction:ti,ab OR Reducing:ti,ab OR Lower:ti,ab) AND (Incidence:ti,ab OR Occurrence:ti,ab OR Transmission:ti,ab OR Secondary:ti,ab)) OR Physiological:ti,ab)

AND

("Adverse effect":ti,ab OR "Adverse effects":ti,ab OR "Adverse event":ti,ab OR "Adverse events":ti,ab OR "Index cases":ti,ab OR "Attack rates":ti,ab OR ((Reduce:ti,ab OR Reduction:ti,ab) AND (Rate:ti,ab OR Rates:ti,ab)) OR Perception:ti,ab OR Prevent:ti,ab OR Adherence:ti,ab)

NOT

([mh "Continuous Positive Airway Pressure"] OR "Positive Airway Pressure":ti,ab OR CPAP:ti,ab OR [mh "Laryngeal Masks"] OR [mh "Intubation, Intratracheal"] OR "Oxygen masks":ti,ab OR "Oxygen mask":ti,ab OR OxyMask:ti,ab OR "Goldman nasal masks":ti,ab OR "Patil-Syracuse Mask":ti,ab OR "Ventilation masks":ti,ab OR "Venti Mask":ti,ab OR "Venturi mask":ti,ab OR "Hockey mask":ti,ab OR "Diving masks":ti,ab OR "Thermoplastic masks":ti,ab OR "Bag valve mask":ti,ab OR "Laryngeal mask":ti,ab OR "Laryngeal masks":ti,ab OR "Oronasal masks":ti,ab OR "Sleep mask":ti,ab) 


\section{Embase}

('Masks'/exp OR 'Respiratory protective devices'/exp OR Facemask:ti,ab OR Facemasks:ti,ab OR Mask:ti,ab OR Masks:ti,ab OR Faceshield:ti,ab OR Faceshields:ti,ab OR Goggles:ti,ab OR "Face shield":ti,ab OR "Face shields":ti,ab OR Visors:ti,ab OR "Face covering":ti,ab)

AND

("Adverse effect":ti,ab OR "Adverse effects":ti,ab OR "Adversely affect":ti,ab OR "Adverse event":ti,ab OR "Adverse events":ti,ab OR Discomfort:ti,ab OR Fatigue:ti,ab OR Pain:ti,ab OR "Difficulty breathing":ti,ab OR "Breathing difficulty":ti,ab OR "Shortness of breath":ti,ab OR "Risk compensation":ti,ab OR Fomite:ti,ab OR Fomites:ti,ab OR Dislike:ti,ab OR "Physiological impacts":ti,ab OR "Physiological impact":ti,ab OR Sweating:ti,ab OR Irritation:ti,ab OR "Psychological reactions":ti,ab OR Fear:ti,ab OR Communication:ti,ab OR "Deaf persons":ti,ab OR Lip-reading:ti,ab OR "Lip reading":ti,ab OR Vitiligo:ti,ab OR Humidity:ti,ab OR "Glasses misting" OR "Face dermatitis":ti,ab OR Acne:ti,ab OR Redness:ti,ab OR Ulcer:ti,ab OR "Speech understanding":ti,ab OR "Pinching of skin":ti,ab OR "Moisture buildup":ti,ab OR "Facial warmth":ti,ab)

AND

(Relieve:ti,ab OR Attitudes:ti,ab OR Induced:ti,ab OR Modified:ti,ab OR Decreased:ti,ab OR Decrease:ti,ab OR Associated:ti,ab OR Impair:ti,ab OR Reduce:ti,ab OR Reducing:ti,ab OR Reduced:ti,ab OR Duration:ti,ab)

AND

("randomized controlled trial":it OR "controlled clinical trial":it OR randomized:ti,ab OR randomised:ti,ab OR placebo:ti,ab OR randomly:ti,ab OR trial:ti,ab OR groups:ti,ab OR 'Epidemiology'/exp OR 'case control study'/exp OR 'cohort analysis'/exp OR "case control":ti,ab OR Cohort:ti,ab OR "Follow up":ti,ab OR Observational:ti,ab OR Longitudinal:ti,ab OR Prospective:ti,ab OR retrospective:ti,ab OR "cross sectional":ti,ab OR 'cross-sectional study'/exp OR Evaluated:ti,ab OR Impact:ti,ab OR Analysis:ti,ab OR Statistics:ti,ab OR Data:ti,ab OR Etiology:ti,ab OR Effect:ti,ab OR Effects:ti,ab OR Affect:ti,ab)

NOT

('positive end expiratory pressure'/exp OR "Positive Airway Pressure":ti,ab OR CPAP:ti,ab OR 'laryngeal mask'/exp OR 'endotracheal intubation'/exp OR "Oxygen masks":ti,ab OR "Oxygen mask":ti,ab OR OxyMask:ti,ab OR "Goldman nasal masks":ti,ab OR "Patil-Syracuse Mask":ti,ab OR "Ventilation masks":ti,ab OR Venti-Mask:ti,ab OR "Venturi mask":ti,ab OR "Hockey mask":ti,ab OR "Diving masks":ti,ab OR "Thermoplastic masks":ti,ab OR Bag-valve-mask:ti,ab OR "Laryngeal mask":ti,ab OR "Laryngeal masks":ti,ab OR "Oronasal masks":ti,ab OR "Sleep mask":ti,ab OR 'letter'/exp OR 'editorial'/exp OR 'case report'/exp)

NOT

('Animal'/exp NOT ('Animal'/exp AND 'Human'/exp))

AND 
[embase]/lim

OR

('Mask'/exp OR 'gas mask'/exp OR Facemask:ti,ab OR Facemasks:ti,ab OR Mask:ti,ab OR Masks:ti,ab OR Faceshield:ti,ab OR Faceshields:ti,ab OR Goggles:ti,ab OR "Face shield":ti,ab OR "Face shields":ti,ab OR Visors:ti,ab OR "Face covering":ti,ab)

AND

('respiratory tract infection'/exp OR Influenza:ti,ab OR 'respiratory tract disease'/exp OR Influenzas:ti,ab OR Influenza-like:ti,ab OR ILI:ti,ab OR "common cold":ti,ab OR colds:ti,ab OR coryza:ti,ab OR 'Coronavirinae'/exp OR 'SARS coronavirus'/exp OR coronavirus:ti,ab OR Coronaviruses:ti,ab OR 'Coronavirus infection'/exp OR 'severe acute respiratory syndrome'/exp OR "severe acute respiratory syndrome":ti,ab OR "severe acute respiratory syndromes":ti,ab OR sars:ti,ab OR 'Pneumovirus'/exp OR 'Human respiratory syncytial virus'/exp OR 'respiratory syncytial virus infection'/exp OR "respiratory syncytial virus":ti,ab OR "respiratory syncytial viruses":ti,ab OR rsv:ti,ab OR parainfluenza:ti,ab OR "Respiratory illness":ti,ab OR ((Transmission:ti,ab) AND (Coughing:ti,ab OR Sneezing:ti,ab)) OR ((respiratory:ti,ab AND Tract:ti,ab) AND (infection:ti,ab OR Infections:ti,ab OR illness:ti,ab)) OR 'communicable disease control'/exp OR 'epidemic'/exp OR 'disease transmission'/exp OR 'Infection Control'/exp OR "Communicable Disease Control":ti,ab OR "Secondary transmission":ti,ab OR ((Reduced:ti,ab OR Reduce:ti,ab OR Reduction:ti,ab OR Reducing:ti,ab OR Lower:ti,ab) AND (Incidence:ti,ab OR Occurrence:ti,ab OR Transmission:ti,ab OR Secondary:ti,ab)) OR Physiological:ti,ab)

AND

('adverse event'/exp OR "Adverse effect":ti,ab OR "Adverse effects":ti,ab OR "Adverse event":ti,ab OR "Adverse events":ti,ab OR "Index cases":ti,ab OR "Attack rates":ti,ab OR ((Reduce:ti,ab OR Reduction:ti,ab) AND (Rate:ti,ab OR Rates:ti,ab)) OR Perception:ti,ab OR Prevent:ti,ab OR Adherence:ti,ab)

AND

("randomized controlled trial":it OR "controlled clinical trial":it OR randomized:ti,ab OR randomised:ti,ab OR placebo:ti,ab OR randomly:ti,ab OR trial:ti,ab OR groups:ti,ab OR 'Epidemiology'/exp OR 'case control study'/exp OR 'cohort analysis'/exp OR "case control":ti,ab OR Cohort:ti,ab OR "Follow up":ti,ab OR Observational:ti,ab OR Longitudinal:ti,ab OR Prospective:ti,ab OR retrospective:ti,ab OR "cross sectional":ti,ab OR 'cross-sectional study'/exp OR Evaluated:ti,ab OR Impact:ti,ab OR Analysis:ti,ab OR Statistics:ti,ab OR Data:ti,ab)

NOT

('positive end expiratory pressure'/exp OR "Positive Airway Pressure":ti,ab OR CPAP:ti,ab OR 'laryngeal mask'/exp OR 'endotracheal intubation'/exp OR "Oxygen masks":ti,ab OR "Oxygen mask":ti,ab OR OxyMask:ti,ab OR "Goldman nasal masks":ti,ab OR "Patil-Syracuse Mask":ti,ab OR "Ventilation masks":ti,ab OR Venti-Mask:ti,ab OR "Venturi mask":ti,ab OR "Hockey mask":ti,ab OR "Diving masks":ti,ab OR "Thermoplastic masks":ti,ab OR Bag-valve-mask:ti,ab OR "Laryngeal 
mask":ti,ab OR "Laryngeal masks":ti,ab OR "Oronasal masks":ti,ab OR "Sleep mask":ti,ab OR "Case Reports":it)

NOT

('Animal'/exp NOT ('Animal'/exp AND 'Human'/exp))

AND

[embase]/lim

\section{Europe PMC}

https://europepmc.org/search?query=\%28TITLE\%3A"masks"\%20AND\%20\%28\%222019nCoV\%22\%200R\%20\%222019nCoV\%22\%200R\%20\%22COVID-19\%22\%200R\%20\%22SARS-CoV2\%22\%200R\%20\%28\%22wuhan\%22\%20AND\%20\%22coronavirus\%22\%29\%200R\%20\%22Coronaviru s\%22\%200R\%20\%22Corona\%20virus\%22\%200R\%20\%22coronavirus $\% 22 \% 200$ R $20 \% 22$ corona\%20viruses $\% 22 \% 200 R \% 20 \% 22$ coronaviruses $\% 22 \% 200 R \% 20 \% 22$ SAR S-CoV\%22\%200R\%20\%220rthocoronavirinae\%22\%200R\%20\%22MERS-

CoV\%22\%20OR\%20\%22Severe\%20Acute\%20Respiratory\%20Syndrome\%22\%200R\%20\%22Middle\% 20East\%20Respiratory\%20Syndrome\%22\%200R\%20\%28\%22SARS\%22\%20AND\%20\%22virus\%22\%29 \%200R\%20\%22soluble\%20ACE2\%22\%200R\%20\%28\%22ACE2\%22\%20AND\%20\%22virus\%22\%29\%20 OR\%20\%28\%22ARDS\%22\%20AND\%20\%22virus\%22\%29\%20or\%20\%28\%22angiotensinconverting\%20enzyme $\% 202 \% 22 \% 20$ AND $\% 20 \% 22$ virus $\% 22 \% 29 \% 29 \% 29 \% 20$ AND $\% 20 \% 28$ SRC $\% 3$ APPR \%29\&page $=1$ 


\section{Appendix 4. List of excluded studies}

\section{Excluded studies from database search}

\begin{tabular}{|c|c|c|}
\hline No. & Reference & $\begin{array}{l}\text { Reason for } \\
\text { exclusion }\end{array}$ \\
\hline 1. & $\begin{array}{l}\text { Ahmad, E. F., et al. (2001). "The effect of wearing the veil by Saudi } \\
\text { ladies on the occurrence of respiratory diseases." J Asthma 38(5): 423- } \\
426 .\end{array}$ & Study type \\
\hline 2. & $\begin{array}{l}\text { Ahmad, I., et al. (2017). "Assessment of knowledge, practice and } \\
\text { barrier in use of facemask among university students." Pakistan } \\
\text { Journal of Medical and Health Sciences 11(4): 1657-1658. }\end{array}$ & $\begin{array}{l}\text { Reported } \\
\text { outcomes }\end{array}$ \\
\hline 3. & $\begin{array}{l}\text { Aiello, A. E., et al. (2010). "A randomized intervention trial of mask use } \\
\text { and hand hygiene to reduce seasonal influenza-like illness and } \\
\text { influenza infections among young adults in a university setting." } \\
\text { International Journal of Infectious Diseases 14: e320. }\end{array}$ & Duplicate \\
\hline 4. & $\begin{array}{l}\text { Aiello, A. E., et al. (2010). "Mask use, hand hygiene, and seasonal } \\
\text { influenza-like illness among young adults: a randomized intervention } \\
\text { trial." J Infect Dis 201(4): 491-498. }\end{array}$ & $\begin{array}{l}\text { No } \\
\text { extractable } \\
\text { data }\end{array}$ \\
\hline 5. & $\begin{array}{l}\text { Akyuz, N., et al. (2014). "How and how much do endoscopy } \\
\text { professionals protect themselves against infection?" Int J Surg 12(7): } \\
720-724 .\end{array}$ & $\begin{array}{l}\text { Reported } \\
\text { outcomes }\end{array}$ \\
\hline 6. & $\begin{array}{l}\text { Albarrak, A. I., et al. (2019). "Middle East Respiratory Syndrome } \\
\text { (MERS): Comparing the knowledge, attitude and practices of different } \\
\text { health care workers." J Infect Public Health. }\end{array}$ & $\begin{array}{l}\text { Reported } \\
\text { outcomes }\end{array}$ \\
\hline 7. & $\begin{array}{l}\text { AlGhamri, A. A., et al. (2013). "The effects of wearing respirators on } \\
\text { human fine motor, visual, and cognitive performance." Ergonomics } \\
56(5): 791-802 \text {. }\end{array}$ & Intervention \\
\hline 8. & $\begin{array}{l}\text { Allsopp, J., et al. (1997). "Survey of the use of personal protective } \\
\text { equipment and prevalence of work related symptoms among dental } \\
\text { staff." Occup Environ Med 54(2): 125-134. }\end{array}$ & $\begin{array}{l}\text { Reported } \\
\text { outcomes }\end{array}$ \\
\hline 9. & $\begin{array}{l}\text { Alqahtani, A. S., et al. (2016). "Exploring barriers to and facilitators of } \\
\text { preventive measures against infectious diseases among Australian Hajj } \\
\text { pilgrims: cross-sectional studies before and after Hajj." Int J Infect Dis } \\
\text { 47: 53-59. }\end{array}$ & $\begin{array}{l}\text { No } \\
\text { extractable } \\
\text { data }\end{array}$ \\
\hline 10. & $\begin{array}{l}\text { Alsarheed, M. (2011). "Children's Perception of Their Dentists." Eur J } \\
\text { Dent 5(2): 186-190. }\end{array}$ & Study type \\
\hline 11. & Aydin, O., et al. (24 April 2020). "Performance of fabrics for home- & Reported \\
\hline
\end{tabular}




\begin{tabular}{|c|c|c|}
\hline & $\begin{array}{l}\text { made masks against spread of respiratory infection through droplets: } \\
\text { a quantitative mechanistic study." PREPRINT (Version } 1 \text { - } \\
\text { 2020.04.19.20071779), Available at: medRxix: } \\
\text { https://doi.org/10.1101/2020.04.19.20071779. }\end{array}$ & outcomes \\
\hline 12. & $\begin{array}{l}\text { Badin, A. (1969). "[The surgeon's fatigue and discomfort behind the } \\
\text { mask]." Gynaecologia 167(5): 430-433. }\end{array}$ & Study type \\
\hline 13. & $\begin{array}{l}\text { Bansal, S., et al. (2009). "Respirator physiological effects under } \\
\text { simulated work conditions." J Occup Environ Hyg 6(4): 221-227. }\end{array}$ & Intervention \\
\hline 14. & $\begin{array}{l}\text { Beuvelet, M., et al. (2017). "Healthcare workers' perception towards } \\
\text { the systematic use of mask during a seasonal influenza outbreak in a } \\
\text { French University Hospital: A descriptive study." Antimicrobial } \\
\text { Resistance and Infection Control } 6 .\end{array}$ & $\begin{array}{l}\text { Unable to } \\
\text { access full } \\
\text { text }\end{array}$ \\
\hline 15. & $\begin{array}{l}\text { Bhoyrul, B., et al. (2019). "A review of non-glove personal protective } \\
\text { equipment-related occupational dermatoses reported to EPIDERM } \\
\text { between } 1993 \text { and 2013." Contact Dermatitis 80(4): } 217-221 .\end{array}$ & Study type \\
\hline 16. & $\begin{array}{l}\text { Bischoff, W., et al. (2017). "Evaluation of a novel powered air-purifying } \\
\text { respirator (PAPR) vs. a N95 respirator mask for the protection against } \\
\text { influenza in a human exposure model." Open Forum Infectious } \\
\text { Diseases 4: S168. }\end{array}$ & $\begin{array}{l}\text { Reported } \\
\text { outcomes }\end{array}$ \\
\hline 17. & $\begin{array}{l}\text { Brandt, C., et al. (2011). "Attitudes of influenza-vaccinated health care } \\
\text { workers toward masks to prevent nosocomial transmission of } \\
\text { influenza." Influenza Other Respir Viruses 5(1): 61-66. }\end{array}$ & Study type \\
\hline 18. & $\begin{array}{l}\text { Buitrago, F. (2010). "Hygienic measures and barriers are effective } \\
\text { strategies to prevent the transmission of viral infections." FMC } \\
\text { Formacion Medica Continuada en Atencion Primaria 17(5): } 361 .\end{array}$ & Study type \\
\hline 19. & $\begin{array}{l}\text { Caretti, D. M. and P. D. Gardner (1999). "Respirator fit factor } \\
\text { performance while sweating." American Industrial Hygiene Association } \\
\text { Journal } 60(1): 84-88 .\end{array}$ & Intervention \\
\hline 20. & $\begin{array}{l}\text { Chan, E. Y., et al. (2015). "Knowledge, attitudes, and practices of Hong } \\
\text { Kong population towards human A/H7N9 influenza pandemic } \\
\text { preparedness, China, 2014." BMC Public Health 15: } 943 .\end{array}$ & $\begin{array}{l}\text { Reported } \\
\text { outcomes }\end{array}$ \\
\hline 21. & $\begin{array}{l}\text { Chan, M. F., et al. (2008). "Investigating the knowledge, attitudes and } \\
\text { practice patterns of operating room staff towards standard and } \\
\text { transmission-based precautions: results of a cluster analysis." J Clin } \\
\text { Nurs } 17(8): \text { 1051-1062. }\end{array}$ & $\begin{array}{l}\text { Reported } \\
\text { outcomes }\end{array}$ \\
\hline 22. & $\begin{array}{l}\text { Chan, M. T., et al. (2013). "Mask ventilation and dispersion of exhaled } \\
\text { air." Am J Respir Crit Care Med 187(7): e12-14. }\end{array}$ & Study type \\
\hline
\end{tabular}




\begin{tabular}{|c|c|c|}
\hline 23. & $\begin{array}{l}\text { Cherrie, J. W., et al. (2019). "In-mask temperature and humidity can } \\
\text { validate respirator wear-time and indicate lung health status." J Expo } \\
\text { Sci Environ Epidemiol 29(4): 578-583. }\end{array}$ & Intervention \\
\hline 24. & $\begin{array}{l}\text { Chung, P. K., et al. (2017). "The process by which perceived autonomy } \\
\text { support predicts motivation, intention, and behavior for seasonal } \\
\text { influenza prevention in Hong Kong older adults." BMC Public Health } \\
\text { 18(1): } 65 .\end{array}$ & Study type \\
\hline 25. & $\begin{array}{l}\text { Coca, A., et al. (2017). "Physiological Evaluation of Personal Protective } \\
\text { Ensembles Recommended for Use in West Africa." Disaster Med Public } \\
\text { Health Prep 11(5): 580-586. }\end{array}$ & Intervention \\
\hline 26. & $\begin{array}{l}\text { Collyer, S. and P. J. Davis (2006). "Effect of facemask use on respiratory } \\
\text { patterns of women in speech and singing." J Speech Lang Hear Res } \\
49(2): 412-423 \text {. }\end{array}$ & $\begin{array}{l}\text { Reported } \\
\text { outcomes }\end{array}$ \\
\hline 27. & $\begin{array}{l}\text { Condon, B. J. and T. Sinha (2010). "Who is that masked person: the use } \\
\text { of face masks on Mexico City public transportation during the } \\
\text { Influenza A (H1N1) outbreak." Health Policy 95(1): 50-56. }\end{array}$ & $\begin{array}{l}\text { Reported } \\
\text { outcomes }\end{array}$ \\
\hline 28. & $\begin{array}{l}\text { Davies, A., et al. (2013). "Testing the efficacy of homemade masks: } \\
\text { would they protect in an influenza pandemic?" Disaster Med Public } \\
\text { Health Prep 7(4): 413-418. }\end{array}$ & $\begin{array}{l}\text { Reported } \\
\text { outcomes }\end{array}$ \\
\hline 29. & $\begin{array}{l}\text { Davis, P. J., et al. (2007). "A survey of Alberta physicians' use of and } \\
\text { attitudes toward face masks and face shields in the operating room } \\
\text { setting." Am J Infect Control 35(7): 455-459. }\end{array}$ & $\begin{array}{l}\text { Reported } \\
\text { outcomes }\end{array}$ \\
\hline 30. & $\begin{array}{l}\text { Del Ferraro, S., et al. (2018). "Hot environment: Effects of a power } \\
\text { assisted filtering device incorporating a full face mask on newton } \\
\text { manikin thermophysiological response." Occupational and } \\
\text { Environmental Medicine 75: A503-A504. }\end{array}$ & Study type \\
\hline 31. & $\begin{array}{l}\text { Del Ferraro, S., et al. (2017). "Thermophysiological response of } \\
\text { Newton manikin equipped with power-assisted filtering device } \\
\text { incorporating a full-face mask in hot environment." Int J Hyperthermia } \\
\text { 33(7): 717-723. }\end{array}$ & Population \\
\hline 32. & $\begin{array}{l}\text { Deris, Z. Z., et al. (2010). "The prevalence of acute respiratory } \\
\text { symptoms and role of protective measures among Malaysian Hajj } \\
\text { pilgrims." Journal of Travel Medicine } 17(2): 82-88 .\end{array}$ & Study type \\
\hline 33. & $\begin{array}{l}\text { Derrick, J. L. and C. D. Gomersall (2005). "Protecting healthcare staff } \\
\text { from severe acute respiratory syndrome: filtration capacity of multiple } \\
\text { surgical masks." J Hosp Infect 59(4): 365-368. }\end{array}$ & $\begin{array}{l}\text { Reported } \\
\text { outcomes }\end{array}$ \\
\hline 34. & Ding, S., et al. (1998). "[Heat strain for personnel wearing three levels & Intervention \\
\hline
\end{tabular}




\begin{tabular}{|c|c|c|}
\hline & $\begin{array}{l}\text { of protective ensembles at moderate and heavy workloads]." Wei } \\
\text { Sheng Yan Jiu 27(6): 361-364. }\end{array}$ & \\
\hline 35. & $\begin{array}{l}\text { DiLeo T, Roberge RJ, Kim JH. Effect of wearing an N95 filtering } \\
\text { facepiece respirator on superomedial orbital infrared indirect brain } \\
\text { temperature measurements. J Clin Monit Comput. 2017;31(1):67-73. }\end{array}$ & $\begin{array}{l}\text { Reported } \\
\text { outcomes }\end{array}$ \\
\hline 36. & $\begin{array}{l}\text { Dong, J. and Y. Chen (2010). "Impact of the bag exchange procedure } \\
\text { on risk of peritonitis." Perit Dial Int 30(4): } 440-447 .\end{array}$ & $\begin{array}{l}\text { Reported } \\
\text { outcomes }\end{array}$ \\
\hline 37. & $\begin{array}{l}\text { Ellison, I. R. T. (2009). "Surgical masks or N95 respirators for the flu?" } \\
\text { Medicine Today 10(12): } 69-70 .\end{array}$ & $\begin{array}{l}\text { Reported } \\
\text { outcomes }\end{array}$ \\
\hline 38. & $\begin{array}{l}\text { Emanuel, R., et al. (2017). "A study of special care dental patient } \\
\text { preference toward choice of mask and visor use by dental clinicians." } \\
\text { Spec Care Dentist 37(4): 164-167. }\end{array}$ & $\begin{array}{l}\text { Reported } \\
\text { outcomes }\end{array}$ \\
\hline 39. & $\begin{array}{l}\text { Fabian, P., et al. (2011). "Influenza virus aerosols in human exhaled } \\
\text { breath: Particle size, culturability, and effect of surgical masks." } \\
\text { Epidemiology 22(1): S51. }\end{array}$ & $\begin{array}{l}\text { Reported } \\
\text { outcomes }\end{array}$ \\
\hline 40. & $\begin{array}{l}\text { Field, M. H., et al. (2020). "Hydrocolloid dressing strip over bridge of } \\
\text { nose to relieve pain and pressure from Filtered Face Piece (FFP) masks } \\
\text { during the coronavirus (COVID-19) pandemic." Ann R Coll Surg Engl } \\
\text { 102(5): 394-396. }\end{array}$ & Study type \\
\hline 41. & $\begin{array}{l}\text { Fierro, J. L., et al. (2015). "Barriers to the Use of PPE to Prevent } \\
\text { Pertussis Exposures in a Pediatric Primary Care Network." J Pediatric } \\
\text { Infect Dis Soc 4(1): 49-56. }\end{array}$ & $\begin{array}{l}\text { Reported } \\
\text { outcomes }\end{array}$ \\
\hline 42. & $\begin{array}{l}\text { Flury, D., et al. (2019). "Health-care associated Influenza Prevention } \\
\text { Project (HAIP): First multicenter surveillance results (nosocomial } \\
\text { influenza and prevention measures)." Antimicrobial Resistance and } \\
\text { Infection Control } 8 .\end{array}$ & $\begin{array}{l}\text { Reported } \\
\text { outcomes }\end{array}$ \\
\hline 43. & $\begin{array}{l}\text { Fox, S. H. and A. B. DuBois (1993). "The effect of evaporative cooling of } \\
\text { respiratory protective devices on skin temperature, thermal sensation, } \\
\text { and comfort." Am Ind Hyg Assoc J 54(12): 705-710. }\end{array}$ & Intervention \\
\hline 44. & $\begin{array}{l}\text { Ganczak, M. and Z. Szych (2007). "Surgical nurses and compliance with } \\
\text { personal protective equipment." J Hosp Infect 66(4): 346-351. }\end{array}$ & $\begin{array}{l}\text { Reported } \\
\text { outcomes }\end{array}$ \\
\hline 45. & $\begin{array}{l}\text { Gu, J., et al. (2015). "Preventive behaviors and mental distress in } \\
\text { response to H1N1 among university students in Guangzhou, China." } \\
\text { Asia Pac J Public Health 27(2): Np1867-1879. }\end{array}$ & $\begin{array}{l}\text { Reported } \\
\text { outcomes }\end{array}$ \\
\hline 46. & $\begin{array}{l}\text { Guo, Y. P., et al. (2008). "Evaluation on masks with exhaust valves and } \\
\text { with exhaust holes from physiological and subjective responses." J }\end{array}$ & Intervention \\
\hline
\end{tabular}




\begin{tabular}{|c|c|c|}
\hline & Physiol Anthropol 27(2): 93-102. & \\
\hline 47. & $\begin{array}{l}\text { Gwosdow, A. R., et al. (1989). "Effect of thermal conditions on the } \\
\text { acceptability of respiratory protective devices on humans at rest." Am } \\
\text { Ind Hyg Assoc J 50(4): 188-195. }\end{array}$ & Intervention \\
\hline 48. & $\begin{array}{l}\text { Hassaniazad, M., et al. (2016). "Preventive measures for Crimean- } \\
\text { Congo hemorrhagic fever in healthcare workers; how high is the } \\
\text { chance of transmission?" Acta Medica Mediterranea 32: 2017-1024. }\end{array}$ & $\begin{array}{l}\text { Reported } \\
\text { outcomes }\end{array}$ \\
\hline 49. & $\begin{array}{l}\text { Harber, P., et al. (1989). "Relationship of subjective tolerance of } \\
\text { respirator loads to physiologic effects and psychophysical load } \\
\text { sensitivity." J Occup Med 31(8): 681-686. }\end{array}$ & Intervention \\
\hline 50. & $\begin{array}{l}\text { Hardis, K. E., et al. (1983). "Correlation of qualitative and quantitative } \\
\text { results from testing respirator fit." Am Ind Hyg Assoc J 44(2): 78-87. }\end{array}$ & Intervention \\
\hline 51. & $\begin{array}{l}\text { Hickey, J., et al. (2014). "Pandemic preparedness: perceptions of } \\
\text { vulnerable migrants in Thailand towards WHO-recommended non- } \\
\text { pharmaceutical interventions: a cross-sectional study." BMC Public } \\
\text { Health 14: } 665 .\end{array}$ & $\begin{array}{l}\text { Reported } \\
\text { outcomes }\end{array}$ \\
\hline 52. & $\begin{array}{l}\text { Hines, S. E., et al. (2019). "User acceptance of reusable respirators in } \\
\text { health care." American Journal of Infection Control 47(6): 648-655. }\end{array}$ & Intervention \\
\hline 53. & $\begin{array}{l}\text { Ho, R. C., et al. (2014). "Impact of } 2013 \text { south Asian haze crisis: study } \\
\text { of physical and psychological symptoms and perceived dangerousness } \\
\text { of pollution level." BMC Psychiatry 14: } 81 \text {. }\end{array}$ & $\begin{array}{l}\text { Reported } \\
\text { outcomes }\end{array}$ \\
\hline 54. & $\begin{array}{l}\text { Huang, W. and L. Morawska (2019). "Face masks could raise pollution } \\
\text { risks." Nature 574(7776): 29-30. }\end{array}$ & Study type \\
\hline 55. & $\begin{array}{l}\text { Huynh. TD (30 March 2020). "The more I fear about COVID-19, the } \\
\text { more I wear medical masks: A survey on risk perception and medical } \\
\text { masks uses." PREPRINT (Version } 1 \text { - 2020.03.26.20044388), Available } \\
\text { at: medRxix: https://doi.org/10.1101/2020.03.26.20044388. }\end{array}$ & $\begin{array}{l}\text { Reported } \\
\text { outcomes }\end{array}$ \\
\hline 56. & $\begin{array}{l}\text { Ioannidou, C., et al. (2010). "Promotion of hygiene measures to } \\
\text { prevent pandemic influenza transmission in greek nursery schools: The } \\
\text { teachers'a perspectives." Acta Paediatrica, International Journal of } \\
\text { Paediatrics 99: } 88 .\end{array}$ & $\begin{array}{l}\text { Reported } \\
\text { outcomes }\end{array}$ \\
\hline 57. & $\begin{array}{l}\text { Jaeger, J. L., et al. (2011). "Transmission of } 2009 \text { pandemic influenza A } \\
\text { (H1N1) virus among healthcare personnel-Southern California, 2009." } \\
\text { Infect Control Hosp Epidemiol 32(12): 1149-1157. }\end{array}$ & $\begin{array}{l}\text { Reported } \\
\text { outcomes }\end{array}$ \\
\hline 58. & $\begin{array}{l}\text { James, R., et al. (1984). "Effects of respirators under heat/work } \\
\text { conditions." Am Ind Hyg Assoc J 45(6): 399-404. }\end{array}$ & Intervention \\
\hline
\end{tabular}




\begin{tabular}{|c|c|c|}
\hline 59. & $\begin{array}{l}\text { Jencsik, T., et al. (2017). "Influenza-related attitudes of healthcare } \\
\text { workers at institutions for acute and chronic diseases." Value in Health } \\
\text { 20(9): A791-A792. }\end{array}$ & Study type \\
\hline 60. & $\begin{array}{l}\text { Johnson, A. T., et al. (2000). "Effect of external dead volume on } \\
\text { performance while wearing a respirator." Aihaj 61(5): 678-684. }\end{array}$ & Intervention \\
\hline 61. & $\begin{array}{l}\text { Johnson, A. T., et al. (2000). "Communication using a telephone while } \\
\text { wearing a respirator." Aihaj 61(2): 264-267. }\end{array}$ & Intervention \\
\hline 62. & $\begin{array}{l}\text { Kawanami, S., et al. (2018). "Physiological effects of wearing powered } \\
\text { airpurifying respirators with different blower system." Occupational } \\
\text { and Environmental Medicine 75: A201. }\end{array}$ & Intervention \\
\hline 63. & $\begin{array}{l}\text { Kim, J. H., et al. (2015). "Effect of wearing an N95 respirator on } \\
\text { infrared tympanic membrane temperature measurements." J Clin } \\
\text { Monit Comput 29(6): 691-695. }\end{array}$ & $\begin{array}{l}\text { Reported } \\
\text { outcomes }\end{array}$ \\
\hline 64. & $\begin{array}{l}\text { Kishimoto, K., et al. (2016). "[Whether Visual Information Loss of } \\
\text { Expression by Community Pharmacist Masks to Effect a Change in } \\
\text { Feeling of Trust among Help-seeker?]." Yakugaku Zasshi 136(10): } \\
\text { 1401-1413. }\end{array}$ & Study type \\
\hline 65. & $\begin{array}{l}\text { Krishna, S., et al. (2019). "The gloves are off: The state of personal } \\
\text { protective equipment (PPE) use in contact, droplet, and standard } \\
\text { precautions at a major teaching hospital." Open Forum Infectious } \\
\text { Diseases 6: S429-S430. }\end{array}$ & Study type \\
\hline 66. & $\begin{array}{l}\text { Kroo, L., et al. (29 April 2020). "Pneumask: Modified Full-Face Snorkel } \\
\text { Masks as Reusable Personal Protective Equipment for Hospital } \\
\text { Personnel." PREPRINT (Version } 1 \text { - 2020.04.24.20078907), Available } \\
\text { at: medRxix: https://doi.org/10.1101/2020.04.24.20078907. }\end{array}$ & Intervention \\
\hline 67. & $\begin{array}{l}\text { Latheef, F., et al. (2015). "Personal protective equipment-associated } \\
\text { dermatoses reported to EPIDERM: A 20-year review." British Journal of } \\
\text { Dermatology 173: 172-173. }\end{array}$ & Duplicate \\
\hline 68. & $\begin{array}{l}\text { Lau, J. T., et al. (2003). "Monitoring community responses to the SARS } \\
\text { epidemic in Hong Kong: from day } 10 \text { to day 62." J Epidemiol } \\
\text { Community Health 57(11): 864-870. }\end{array}$ & $\begin{array}{l}\text { Reported } \\
\text { outcomes }\end{array}$ \\
\hline 69. & $\begin{array}{l}\text { Leung, N. H., et al. (06 March 2020). "Respiratory Virus Shedding in } \\
\text { Exhaled Breath and Efficacy of Face Masks." PREPRINT (Version 1), } \\
\text { Available at: Research Square [+https://doi.org/10.21203/rs.3.rs- } \\
\text { 16836/v1+],. }\end{array}$ & $\begin{array}{l}\text { Reported } \\
\text { outcomes }\end{array}$ \\
\hline 70. & $\begin{array}{l}\text { Lee, H. P. and Y. Wang de (2011). "Objective assessment of increase in } \\
\text { breathing resistance of N95 respirators on human subjects." Ann }\end{array}$ & $\begin{array}{l}\text { Reported } \\
\text { outcomes }\end{array}$ \\
\hline
\end{tabular}




\begin{tabular}{|c|c|c|}
\hline & Occup Hyg 55(8): 917-921. & \\
\hline 71. & $\begin{array}{l}\text { Lee, J. A., et al. (2017). "Compliance of personal protective equipment } \\
\text { in a hospital." Antimicrobial Resistance and Infection Control } 6 .\end{array}$ & $\begin{array}{l}\text { Reported } \\
\text { outcomes }\end{array}$ \\
\hline 72. & $\begin{array}{l}\text { Li, Y., et al. (2006). "Antimicrobial effect of surgical masks coated with } \\
\text { nanoparticles." J Hosp Infect 62(1): 58-63. }\end{array}$ & Intervention \\
\hline 73. & $\begin{array}{l}\text { Li, C., et al. (2020). "[Management and prevention of common skin } \\
\text { problems during epidemic prevention and control of COVID-19]." Nan } \\
\text { Fang Yi Ke Da Xue Xue Bao 40(2): 168-170. }\end{array}$ & $\begin{array}{l}\text { Reported } \\
\text { outcomes }\end{array}$ \\
\hline 74. & $\begin{array}{l}\text { Loeb, M., et al. (2009). "Surgical mask vs N95 respirator for preventing } \\
\text { influenza among health care workers: a randomized trial." Jama } \\
\text { 302(17): } 1865-1871 .\end{array}$ & $\begin{array}{l}\text { Reported } \\
\text { outcomes }\end{array}$ \\
\hline 75. & $\begin{array}{l}\text { Loibner, M., et al. (2019). "Limiting factors for wearing personal } \\
\text { protective equipment (PPE) in a health care environment evaluated in } \\
\text { a randomised study." PLoS One 14(1): e0210775. }\end{array}$ & Intervention \\
\hline 76. & $\begin{array}{l}\text { Lonnroth, E. C. and H. Shahnavaz (1998). "Adverse health reactions in } \\
\text { skin, eyes, and respiratory tract among dental personnel in Sweden." } \\
\text { Swed Dent J 22(1): 33-45. }\end{array}$ & $\begin{array}{l}\text { Reported } \\
\text { outcomes }\end{array}$ \\
\hline 77. & $\begin{array}{l}\text { Lopes, A. C., et al. (2008). "[Adherence to standard precautions by the } \\
\text { public pre-hospital health team in Belo Horizonte, Minas Gerais State, } \\
\text { Brazil]." Cad Saude Publica 24(6): 1387-1396. }\end{array}$ & $\begin{array}{l}\text { Reported } \\
\text { outcomes }\end{array}$ \\
\hline 78. & $\begin{array}{l}\text { Lunding, S., et al. (1998). "[Poor compliance with universal precautions } \\
\text { among Danish physicians]." Ugeskr Laeger 160(12): 1789-1793. }\end{array}$ & $\begin{array}{l}\text { Reported } \\
\text { outcomes }\end{array}$ \\
\hline 79. & $\begin{array}{l}\text { Lutz, M., et al. (2019). "Physiological effects of a spit sock." Am J } \\
\text { Emerg Med 37(2): 291-293. }\end{array}$ & Intervention \\
\hline 80. & $\begin{array}{l}\text { Ma, X., et al. (2014). "Knowledge, attitudes and practices relating to } \\
\text { influenza A(H7N9) risk among live poultry traders in Guangzhou City, } \\
\text { China." BMC Infect Dis 14: } 554 \text {. }\end{array}$ & $\begin{array}{l}\text { Reported } \\
\text { outcomes }\end{array}$ \\
\hline 81. & $\begin{array}{l}\text { Maclntyre, C. R., et al. (2016). "Cluster randomised controlled trial to } \\
\text { examine medical mask use as source control for people with } \\
\text { respiratory illness." BMJ Open 6(12): e012330. }\end{array}$ & $\begin{array}{l}\text { Reported } \\
\text { outcomes }\end{array}$ \\
\hline 82. & $\begin{array}{l}\text { Martins, R. S., et al. (2013). "Adequacy to the use of personal } \\
\text { protective equipment in the isolations of emergency." Antimicrobial } \\
\text { Resistance and Infection Control } 2 .\end{array}$ & $\begin{array}{l}\text { Reported } \\
\text { outcomes }\end{array}$ \\
\hline 83. & $\begin{array}{l}\text { Maschmeyer, G., et al. (2009). "A prospective, randomised study on } \\
\text { the use of well-fitting masks for prevention of invasive aspergillosis in }\end{array}$ & Intervention \\
\hline
\end{tabular}




\begin{tabular}{|c|c|c|}
\hline & high-risk patients." Ann Oncol 20(9): 1560-1564. & \\
\hline 84. & $\begin{array}{l}\text { Mathews, R., et al. (2008). "Provision and use of personal protective } \\
\text { equipment and safety devices in the National Study to Prevent Blood } \\
\text { Exposure in Paramedics." Am J Infect Control 36(10): 743-749. }\end{array}$ & Study type \\
\hline 85. & $\begin{array}{l}\text { Mauritzson-Sandberg, E. (1995). "An evaluation of respiratory } \\
\text { protective devices used in children's evacuation." Ergonomics 38(4): } \\
707-713 .\end{array}$ & $\begin{array}{l}\text { Purpose of } \\
\text { study }\end{array}$ \\
\hline 86. & $\begin{array}{l}\text { Meyer, J. P., et al. (1997). "Field study of subjective assessment of } \\
\text { negative pressure half-masks. Influence of the work conditions on } \\
\text { comfort and efficiency." Appl Ergon 28(5-6): 331-338. }\end{array}$ & $\begin{array}{l}\text { Purpose of } \\
\text { study }\end{array}$ \\
\hline 87. & $\begin{array}{l}\text { Millqvist, E., et al. (1995). "Prevention of asthma induced by cold air by } \\
\text { cellulose-fabric face mask." Allergy 50(3): } 221-224 \text {. }\end{array}$ & $\begin{array}{l}\text { Reported } \\
\text { outcomes }\end{array}$ \\
\hline 88. & $\begin{array}{l}\text { Morishima, M. and K. Kishida (2018). "Understanding attitudes toward } \\
\text { hygiene mask use in Japanese daily life by using a repeated cross- } \\
\text { sectional survey." Work 61(2): 303-311. }\end{array}$ & Study type \\
\hline 89. & $\begin{array}{l}\text { Morishima, M., et al. (2011). "An investigation of the use of hay fever } \\
\text { masks for the youth." J Hum Ergol (Tokyo) 40(1): 151-156. }\end{array}$ & Intervention \\
\hline 90. & $\begin{array}{l}\text { Moser, A., et al. (2015). "Rates and determinants of vaccination } \\
\text { against seasonal and pandemic influenza in Swiss prehospital } \\
\text { emergency medical services workers." Praxis 104: } 142 .\end{array}$ & Study type \\
\hline 91. & $\begin{array}{l}\text { Moser, A., et al. (2016). "Vaccination Against Seasonal or Pandemic } \\
\text { Influenza in Emergency Medical Services." Prehosp Disaster Med } \\
\text { 31(2): 155-162. }\end{array}$ & Study type \\
\hline 92. & $\begin{array}{l}\text { Motoyama, Y. L., et al. (2016). "Airflow-Restricting Mask Reduces } \\
\text { Acute Performance in Resistance Exercise." Sports (Basel) 4(4). }\end{array}$ & Intervention \\
\hline 93. & $\begin{array}{l}\text { Nichol, K., et al. (2008). "The individual, environmental, and } \\
\text { organizational factors that influence nurses' use of facial protection to } \\
\text { prevent occupational transmission of communicable respiratory illness } \\
\text { in acute care hospitals." Am J Infect Control 36(7): 481-487. }\end{array}$ & Study type \\
\hline 94. & $\begin{array}{l}\text { Nichol, K., et al. (2013). "Behind the mask: Determinants of nurse's } \\
\text { adherence to facial protective equipment." Am J Infect Control 41(1): } \\
\text { 8-13. }\end{array}$ & Study type \\
\hline 95. & $\begin{array}{l}\text { Nielsen, R., et al. (1987). "The effect of temperature and humidity } \\
\text { levels in a protective mask on user acceptability during exercise." Am } \\
\text { Ind Hyg Assoc J 48(7): 639-645. }\end{array}$ & Intervention \\
\hline
\end{tabular}




\begin{tabular}{|c|c|c|}
\hline 96. & $\begin{array}{l}\text { Palmiero, A. J., et al. (2016). "Speech intelligibility assessment of } \\
\text { protective facemasks and air-purifying respirators." J Occup Environ } \\
\text { Hyg 13(12): 960-968. }\end{array}$ & Study type \\
\hline 97. & $\begin{array}{l}\text { Parveen, S. N. A., et al. (2018). "Identifying acceptable and feasible } \\
\text { infection control interventions for nipah encephalitis outbreaks in } \\
\text { bangladesh." American Journal of Infection Control 46(6): S24. }\end{array}$ & Study type \\
\hline 98. & $\begin{array}{l}\text { Peponis, T., et al. (2017). "Trauma team utilization of universal } \\
\text { precautions: if you see something, say something." Eur J Trauma } \\
\text { Emerg Surg 43(1): } 145-150 .\end{array}$ & $\begin{array}{l}\text { Reported } \\
\text { outcomes }\end{array}$ \\
\hline 99. & $\begin{array}{l}\text { Perez, V., et al. (2012). "Stress, adherence to preventive measures for } \\
\text { reducing influenza transmission and influenza-like illness." J Epidemiol } \\
\text { Community Health 66(7): 605-610. }\end{array}$ & $\begin{array}{l}\text { No } \\
\text { extractable } \\
\text { data }\end{array}$ \\
\hline 100. & $\begin{array}{l}\text { Radonovich Jr, L. J., et al. (2009). "Diminished speech intelligibility } \\
\text { associated with certain types of respirators worn by healthcare } \\
\text { workers." Journal of Occupational and Environmental Hygiene } 7(1) \text { : } \\
63-70 .\end{array}$ & Intervention \\
\hline 101. & $\begin{array}{l}\text { Radonovich, L., et al. (2018). "Results of the respiratory protection } \\
\text { effectiveness clinical trial (respect)." Open Forum Infectious Diseases } \\
\text { 5: S51. }\end{array}$ & Duplicate \\
\hline 102. & $\begin{array}{l}\text { Ramirez, J. A. and P. T. O'Shaughnessy (2016). "The effect of simulated } \\
\text { air conditions on N95 filtering facepiece respirators performance." J } \\
\text { Occup Environ Hyg 13(7): 491-500. }\end{array}$ & Study type \\
\hline 103. & $\begin{array}{l}\text { Raven, P. B., et al. (1977). "Maximal stress test performance while } \\
\text { wearing a self-contained breathing apparatus." J Occup Med 19(12): } \\
\text { 802-806. }\end{array}$ & Intervention \\
\hline 104. & $\begin{array}{l}\text { Rengasamy, S. and B. C. Eimer (2013). "N95-companion measurement } \\
\text { of cout/cin ratios for two n95 filtering facepiece respirators and one } \\
\text { surgical mask." J Occup Environ Hyg 10(10): 527-532. }\end{array}$ & Population \\
\hline 105. & $\begin{array}{l}\text { Roberge, R. (2011). "Facemask use by children during infectious } \\
\text { disease outbreaks." Biosecur Bioterror 9(3): 225-231. }\end{array}$ & Study type \\
\hline 106. & $\begin{array}{l}\text { Roberge, R. J., et al. (2010). "Surgical mask placement over N95 } \\
\text { filtering facepiece respirators: physiological effects on healthcare } \\
\text { workers." Respirology 15(3): 516-521. }\end{array}$ & Intervention \\
\hline 107. & $\begin{array}{l}\text { Roberge, R. J., et al. (2010). "Reusable elastomeric air-purifying } \\
\text { respirators: physiologic impact on health care workers." Am J Infect } \\
\text { Control 38(5): 381-386. }\end{array}$ & Intervention \\
\hline
\end{tabular}




\begin{tabular}{|c|c|c|}
\hline 108. & $\begin{array}{l}\text { Rozzi, T., et al. (2012). "Pilot study of aromatic hydrocarbon } \\
\text { adsorption characteristics of disposable filtering facepiece respirators } \\
\text { that contain activated carbon." J Occup Environ Hyg 9(11): 624-629. }\end{array}$ & $\begin{array}{l}\text { Purpose of } \\
\text { study }\end{array}$ \\
\hline 109. & $\begin{array}{l}\text { van der Sande, M., et al. (2008). "Professional and home-made face } \\
\text { masks reduce exposure to respiratory infections among the general } \\
\text { population." PLoS ONE 3(7): e2618. }\end{array}$ & $\begin{array}{l}\text { Reported } \\
\text { outcomes }\end{array}$ \\
\hline 110. & $\begin{array}{l}\text { Santos, P. B., et al. (2013). "Adherence to biosafety practices by } \\
\text { nursing staff in the face of situations of occupational risk." } \\
\text { Antimicrobial Resistance and Infection Control } 2 \text {. }\end{array}$ & $\begin{array}{l}\text { Unable to } \\
\text { access full } \\
\text { text }\end{array}$ \\
\hline 111. & $\begin{array}{l}\text { Schmitt, C. H. (2004). "Secrets behind the mask." US News World Rep } \\
\text { 137(4): 37-41. }\end{array}$ & Study type \\
\hline 112. & $\begin{array}{l}\text { Seliga, R., et al. (1991). "Effect of work load and respirator wear on } \\
\text { postural stability, heart rate, and perceived exertion." Am Ind Hyg } \\
\text { Assoc J 52(10): 417-422. }\end{array}$ & Intervention \\
\hline 113. & $\begin{array}{l}\text { Seng, M., et al. (2018). "Comfort and exertion while using filtering } \\
\text { facepiece respirators with exhalation valve and an active venting } \\
\text { system among male military personnel." Singapore Med J 59(6): 327- } \\
334 .\end{array}$ & $\begin{array}{l}\text { Purpose of } \\
\text { study }\end{array}$ \\
\hline 114. & $\begin{array}{l}\text { Smith, C. L., et al. (2013). "Carbon dioxide rebreathing in respiratory } \\
\text { protective devices: influence of speech and work rate in full-face } \\
\text { masks." Ergonomics 56(5): 781-790. }\end{array}$ & Intervention \\
\hline 115. & $\begin{array}{l}\text { Sokol, K. A., et al. (2016). "Masks for prevention of respiratory viruses } \\
\text { on the BMT unit: results of a quality initiative." Transpl Infect Dis } \\
\text { 18(6): } 965-967 .\end{array}$ & $\begin{array}{l}\text { Reported } \\
\text { outcomes }\end{array}$ \\
\hline 116. & $\begin{array}{l}\text { Stebbins, S., et al. (2009). "Using nonpharmaceutical interventions to } \\
\text { prevent influenza transmission in elementary school children: parent } \\
\text { and teacher perspectives." J Public Health Manag Pract 15(2): 112- } \\
117 .\end{array}$ & $\begin{array}{l}\text { Reported } \\
\text { outcomes }\end{array}$ \\
\hline 117. & $\begin{array}{l}\text { Stockwell, R. E., et al. (2018). "Prolonged wear of face masks prevents } \\
\text { the release of pseudomonas aeruginosa aerosols during coughing in } \\
\text { people with cystic fibrosis." Pediatric Pulmonology 53: } 269 \text {. }\end{array}$ & $\begin{array}{l}\text { Unable to } \\
\text { access full } \\
\text { text }\end{array}$ \\
\hline 118. & $\begin{array}{l}\text { Strauch, A. L., et al. (2016). "Assessing the efficacy of tabs on filtering } \\
\text { facepiece respirator straps to increase proper doffing techniques while } \\
\text { reducing contact transmission of pathogens." J Occup Environ Hyg } \\
\text { 13(10): 794-801. }\end{array}$ & Intervention \\
\hline 119. & $\begin{array}{l}\text { Sullivan, K. (1993). "Surgical face masks: protection of self or patient?" } \\
\text { N Z Dent J 89(398): } 137 .\end{array}$ & Study type \\
\hline
\end{tabular}




\begin{tabular}{|c|c|c|}
\hline 120. & $\begin{array}{l}\text { Suruda, A., et al. (2003). "Fatal injuries in the United States involving } \\
\text { respirators, 1984-1995." Appl Occup Environ Hyg 18(4): 289-292. }\end{array}$ & Study type \\
\hline 121. & $\begin{array}{l}\text { Tak, C. N., et al. (2009). "Preventing healthcare workers from acquiring } \\
\text { influenza." Infection Control and Hospital Epidemiology 30(3): 292- } \\
295 .\end{array}$ & $\begin{array}{l}\text { Reported } \\
\text { outcomes }\end{array}$ \\
\hline 122. & $\begin{array}{l}\text { Tan, K. T. and M. W. Greaves (2004). "N95 acne." Int J Dermatol 43(7): } \\
\text { 522-523. }\end{array}$ & Study type \\
\hline 123. & $\begin{array}{l}\text { Tang, C. S. and C. Y. Wong (2004). "Factors influencing the wearing of } \\
\text { facemasks to prevent the severe acute respiratory syndrome among } \\
\text { adult Chinese in Hong Kong." Prev Med 39(6): 1187-1193. }\end{array}$ & $\begin{array}{l}\text { Reported } \\
\text { outcomes }\end{array}$ \\
\hline 124. & $\begin{array}{l}\text { Tataris, K., et al. (2010). "Patient attitudes and compliance while } \\
\text { wearing surgical masks to prevent disease transmission." Academic } \\
\text { Emergency Medicine 17: S58. }\end{array}$ & $\begin{array}{l}\text { Unable to } \\
\text { access full } \\
\text { text }\end{array}$ \\
\hline 125. & $\begin{array}{l}\text { Vanjak, D., et al. (2006). "[Cases of pertussis among healthcare } \\
\text { workers in a maternity ward: management of a health alert]." Med } \\
\text { Mal Infect 36(3): 151-156. }\end{array}$ & $\begin{array}{l}\text { Duplicate } \\
\text { reference }\end{array}$ \\
\hline 126. & $\begin{array}{l}\text { Vijaya, K., et al. (2005). "Behaviour of Singaporeans during the SARS } \\
\text { outbreak: The impact of anxiety and public satisfaction with media } \\
\text { information." International Journal of Health Promotion and Education } \\
43(1): 17-22 \text {. }\end{array}$ & $\begin{array}{l}\text { Reported } \\
\text { outcomes }\end{array}$ \\
\hline 127. & $\begin{array}{l}\text { Wong, S. Y., et al. (2012). "Primary care physicians' response to } \\
\text { pandemic influenza in Hong Kong: a mixed quantitative and qualitative } \\
\text { study." Int J Infect Dis 16(9): e687-691. }\end{array}$ & $\begin{array}{l}\text { Reported } \\
\text { outcomes }\end{array}$ \\
\hline 128. & $\begin{array}{l}\text { Yang, P., et al. (2011). "Mask-wearing and respiratory infection in } \\
\text { healthcare workers in Beijing, China." Braz J Infect Dis 15(2): 102-108. }\end{array}$ & Study type \\
\hline
\end{tabular}

\section{Excluded studies identified from Forward \& Backward citation analysis}

\begin{tabular}{|r|l|l|}
\hline 129. & $\begin{array}{l}\text { Barratt, R., et al. (2019). "Enablers of, and barriers to, optimal glove } \\
\text { and mask use for routine care in the emergency department: an } \\
\text { ethnographic study of Australian clinicians." Australasian Emergency } \\
\text { Care. }\end{array}$ & Study type \\
\hline 130. & $\begin{array}{l}\text { Caretti, D. M. and L. C. Strickler (2003). "Speech intelligibility during } \\
\text { respirator wear: Influences of respirator speech diaphragm size and } \\
\text { background noise." American Industrial Hygiene Association Journal } \\
64(6): 846-850 .\end{array}$ & Intervention \\
\hline 131. & Chughtai, A. A., et al. (2015). "Practices around the use of masks and & Reported \\
\hline
\end{tabular}




\begin{tabular}{|c|c|c|}
\hline & $\begin{array}{l}\text { respirators among hospital health care workers in } 3 \text { diverse } \\
\text { populations." American Journal of Infection Control 43(10): 1116- } \\
1118 .\end{array}$ & outcomes \\
\hline 132. & $\begin{array}{l}\text { Enerson, D. M., et al. (1967). "Heat and moisture trapping beneath } \\
\text { surgical face masks: a consideration of factors affecting the surgeon's } \\
\text { discomfort and performance." Surgery } 62(6): 1007-1016 .\end{array}$ & $\begin{array}{l}\text { Reported } \\
\text { outcomes }\end{array}$ \\
\hline 133. & $\begin{array}{l}\text { Goh, D. Y. T., et al. (2019). "A randomised clinical trial to evaluate the } \\
\text { safety, fit, comfort of a novel N95 mask in children." Scientific Reports } \\
9(1) .\end{array}$ & $\begin{array}{l}\text { Purpose of } \\
\text { study }\end{array}$ \\
\hline 134. & $\begin{array}{l}\text { Harber } \mathrm{P} \text {, Bansal S, Santiago S, et al. Multidomain subjective response } \\
\text { to respirator use during simulated work. Journal of Occupational and } \\
\text { Environmental Medicine. } 2009 ; 51(1): 38-45 \text {. }\end{array}$ & $\begin{array}{l}\text { Reported } \\
\text { outcomes }\end{array}$ \\
\hline 135. & $\begin{array}{l}\text { Harber, P., et al. (2010). "Respirator physiologic impact in persons } \\
\text { with mild respiratory disease." Journal of Occupational and } \\
\text { Environmental Medicine 52(2): 155-162. }\end{array}$ & Intervention \\
\hline 136. & $\begin{array}{l}\text { Harber, P., et al. (2011). "Respirator impact on work task } \\
\text { performance." Journal of Occupational and Environmental Medicine } \\
53(1): 22-26 .\end{array}$ & $\begin{array}{l}\text { Reported } \\
\text { outcomes }\end{array}$ \\
\hline 137. & $\begin{array}{l}\text { Honarbakhsh, M., et al. (2018). "Knowledge, perceptions and } \\
\text { practices of healthcare workers regarding the use of respiratory } \\
\text { protection equipment at Iran hospitals." Journal of Infection } \\
\text { Prevention 19(1): } 29-36 \text {. }\end{array}$ & $\begin{array}{l}\text { Reported } \\
\text { outcomes }\end{array}$ \\
\hline 138. & $\begin{array}{l}\text { Jacobs, J. L., et al. (2009). "Use of surgical face masks to reduce the } \\
\text { incidence of the common cold among health care workers in Japan: A } \\
\text { randomized controlled trial." American Journal of Infection Control } \\
37(5): 417-419 \text {. }\end{array}$ & Duplicate \\
\hline 139. & $\begin{array}{l}\text { Jones, J. G. (1991). "The physiological cost of wearing a disposable } \\
\text { respirator." American Industrial Hygiene Association Journal 52(6): } \\
219-225 .\end{array}$ & Intervention \\
\hline 140. & $\begin{array}{l}\text { Kim, J. H., et al. (2013). "Pulmonary and heart rate responses to } \\
\text { wearing N95 filtering facepiece respirators." American Journal of } \\
\text { Infection Control 41(1): } 24-27 \text {. }\end{array}$ & $\begin{array}{l}\text { Reported } \\
\text { outcomes }\end{array}$ \\
\hline 141. & $\begin{array}{l}\text { Kim, J. H., et al. (2015). "Pressure drop of filtering facepiece } \\
\text { respirators: How low should we go?" International Journal of } \\
\text { Occupational Medicine and Environmental Health 28(1): 71-80. }\end{array}$ & Intervention \\
\hline 142. & $\begin{array}{l}\text { Kim, J. H., et al. (2016). "Physiologic and fit factor profiles of N95 and } \\
\text { P100 filtering facepiece respirators for use in hot, humid }\end{array}$ & Reported \\
\hline
\end{tabular}




\begin{tabular}{|c|c|c|}
\hline & environments." American Journal of Infection Control 44(2): 194-198. & outcomes \\
\hline 143. & $\begin{array}{l}\text { Lim, E. C. H., et al. (2007). "Headaches and the N95 face-mask } \\
\text { amongst healthcare providers [2]." Acta Neurologica Scandinavica } \\
\text { 116(1): } 73 .\end{array}$ & Duplicate \\
\hline 144. & $\begin{array}{l}\text { Li Y, Tokura H, Guo YP, et al. Effects of wearing N95 and surgical } \\
\text { facemasks on heart rate, thermal stress and subjective sensations. } \\
\text { International Archives of Occupational and Environmental Health. } \\
\text { 2005;78(6):501-509. }\end{array}$ & $\begin{array}{l}\text { No extractable } \\
\text { data }\end{array}$ \\
\hline 145. & $\begin{array}{l}\text { Lin, Y. C. and C. P. Chen (2019). "Thermoregulation and thermal } \\
\text { sensation in response to wearing tight-fitting respirators and } \\
\text { exercising in hot-and-humid indoor environment." Building and } \\
\text { Environment } 160 \text {. }\end{array}$ & Intervention \\
\hline 146. & $\begin{array}{l}\text { Locatelli, S. M., et al. (2014). "Health care workers' reported } \\
\text { discomfort while wearing filtering face-piece respirators." Workplace } \\
\text { Health and Safety 62(9): 362-368. }\end{array}$ & $\begin{array}{l}\text { Reported } \\
\text { outcomes }\end{array}$ \\
\hline 147. & $\begin{array}{l}\text { Luximon, Y., et al. (2016). "Time dependent infrared thermographic } \\
\text { evaluation of facemasks." Work 54(4): 825-835. }\end{array}$ & $\begin{array}{l}\text { Reported } \\
\text { outcomes }\end{array}$ \\
\hline 148. & $\begin{array}{l}\text { Maclntyre, C. R., et al. (2014). "Efficacy of face masks and respirators } \\
\text { in preventing upper respiratory tract bacterial colonization and co- } \\
\text { infection in hospital healthcare workers." Preventive Medicine 62: 1- } \\
7 .\end{array}$ & $\begin{array}{l}\text { Reported } \\
\text { outcomes }\end{array}$ \\
\hline 149. & $\begin{array}{l}\text { Maclntyre, C. R., et al. (2013). "A randomized clinical trial of three } \\
\text { options for N95 respirators and medical masks in health workers." } \\
\text { American Journal of Respiratory and Critical Care Medicine 187(9): } \\
960-966 .\end{array}$ & Duplicate \\
\hline 150. & $\begin{array}{l}\text { Mauritzson-Sandberg, E. V. A. (1991). "Psychological effects on } \\
\text { prolonged use of respiratory protective devices in children." } \\
\text { Ergonomics 34(3): 313-319. }\end{array}$ & $\begin{array}{l}\text { Reported } \\
\text { outcomes }\end{array}$ \\
\hline 151. & $\begin{array}{l}\text { McDiarmid, M., et al. (2020). "N95 Respirators vs Medical Masks in } \\
\text { Outpatient Settings." JAMA - Journal of the American Medical } \\
\text { Association 323(8): } 789 .\end{array}$ & Study type \\
\hline 152. & $\begin{array}{l}\text { Morishima, M., et al. (2014). "Experiences and problems with hygiene } \\
\text { masks reported by japanese hay fever sufferers." International Journal } \\
\text { of Clothing Science and Technology 26(4): } 262-273 \text {. }\end{array}$ & Intervention \\
\hline 153. & $\begin{array}{l}\text { Morishima, M., et al. (2017). "Problems related to mask use in hay } \\
\text { fever sufferers by repeated surveys." International Journal of Clothing } \\
\text { Science and Technology 29(1): 123-134. }\end{array}$ & $\begin{array}{l}\text { Purpose of } \\
\text { study }\end{array}$ \\
\hline
\end{tabular}




\begin{tabular}{|c|c|c|}
\hline 154. & $\begin{array}{l}\text { Ong, J. J. Y., et al. (2020). "Headaches Associated With Personal } \\
\text { Protective Equipment - A Cross-Sectional Study Among Frontline } \\
\text { Healthcare Workers During COVID-19." Headache 60(5): 864-877. }\end{array}$ & Duplicate \\
\hline 155. & $\begin{array}{l}\text { Phin NF, Rylands AJ, Allan J, Edwards C, Enstone JE, Nguyen-Van-Tam } \\
\text { JS. Personal protective equipment in an influenza pandemic: a UK } \\
\text { simulation exercise. Journal of Hospital Infection. 2009;71(1):15-21. }\end{array}$ & Study design \\
\hline 156. & $\begin{array}{l}\text { Radonovich Jr, L. J., et al. (2010). "Diminished speech intelligibility } \\
\text { associated with certain types of respirators worn by healthcare } \\
\text { workers." Journal of Occupational and Environmental Hygiene 7(1): } \\
63-70 .\end{array}$ & Intervention \\
\hline 157. & $\begin{array}{l}\text { Radonovich, L. J., et al. (2019). "A tolerability assessment of new } \\
\text { respiratory protective devices developed for health care personnel: A } \\
\text { randomized simulated clinical study." PLoS ONE 14(1). }\end{array}$ & $\begin{array}{l}\text { No extractable } \\
\text { data }\end{array}$ \\
\hline 158. & $\begin{array}{l}\text { Roberge, R., et al. (2012). "Thermal burden of N95 filtering facepiece } \\
\text { respirators." Annals of Occupational Hygiene 56(7): 808-814. }\end{array}$ & $\begin{array}{l}\text { Reported } \\
\text { outcomes }\end{array}$ \\
\hline 159. & $\begin{array}{l}\text { Roberge, R. J. (2008). "Effect of surgical masks worn concurrently over } \\
\text { N95 filtering facepiece respirators: Extended service life versus } \\
\text { increased user burden." Journal of Public Health Management and } \\
\text { Practice 14(2): E19-E26. }\end{array}$ & Study type \\
\hline 160. & $\begin{array}{l}\text { Roberge RJ, Coca A, Williams WJ, Powell JB, Palmiero AJ. Physiological } \\
\text { impact of the n95 filtering facepiece respirator on healthcare workers. } \\
\text { Respiratory Care. 2010;55(5):569-577. }\end{array}$ & Intervention \\
\hline 161. & $\begin{array}{l}\text { Roberge, R. J., et al. (2010). "Effect of exhaled moisture on breathing } \\
\text { resistance of N95 filtering facepiece respirators." Annals of } \\
\text { Occupational Hygiene 54(6): 671-677. }\end{array}$ & Study type \\
\hline 162. & $\begin{array}{l}\text { Roberge, R. J., et al. (2012). "N95 filtering facepiece respirator } \\
\text { deadspace temperature and humidity." Journal of Occupational and } \\
\text { Environmental Hygiene 9(3): 166-171. }\end{array}$ & $\begin{array}{l}\text { Reported } \\
\text { outcomes }\end{array}$ \\
\hline 163. & $\begin{array}{l}\text { Roberge, R. J., et al. (2013). "Impact of low filter resistances on } \\
\text { subjective and physiological responses to filtering facepiece } \\
\text { respirators." PLoS ONE 8(12). }\end{array}$ & Intervention \\
\hline 164. & $\begin{array}{l}\text { Roberge RJ, Kim JH, Powell JB. N95 respirator use during advanced } \\
\text { pregnancy. American Journal of Infection Control. 2014;42(10):1097- } \\
1100 .\end{array}$ & $\begin{array}{l}\text { No extractable } \\
\text { data }\end{array}$ \\
\hline 165. & $\begin{array}{l}\text { Sakaguchi, H., et al. (2010). "Maintenance of influenza virus infectivity } \\
\text { on the surfaces of personal protective equipment and clothing used in } \\
\text { healthcare settings." Environmental Health and Preventive Medicine }\end{array}$ & $\begin{array}{l}\text { Purpose of } \\
\text { study }\end{array}$ \\
\hline
\end{tabular}




\begin{tabular}{|c|c|c|}
\hline & 15(6): 344-349. & \\
\hline 166. & $\begin{array}{l}\text { Shi, J., et al. (2017). "Cardiovascular benefits of wearing particulate- } \\
\text { filtering respirators: A randomized crossover trial." Environmental } \\
\text { Health Perspectives } 125(2): 175-180 .\end{array}$ & $\begin{array}{l}\text { Purpose of } \\
\text { study }\end{array}$ \\
\hline 167. & $\begin{array}{l}\text { Shigayeva, A., et al. (2007). "Factors associated with critical-care } \\
\text { healthcare workers' adherence to recommended barrier precautions } \\
\text { during the Toronto severe acute respiratory syndrome outbreak." } \\
\text { Infection Control and Hospital Epidemiology 28(11): 1275-1283. }\end{array}$ & $\begin{array}{l}\text { No extractable } \\
\text { data }\end{array}$ \\
\hline 168. & $\begin{array}{l}\text { Skaria, S. D. and G. C. Smaldone (2014). "Respiratory source Control } \\
\text { using surgical masks with nanofiber media." Annals of Occupational } \\
\text { Hygiene 58(6): 771-781. }\end{array}$ & $\begin{array}{l}\text { Purpose of } \\
\text { study }\end{array}$ \\
\hline 169. & $\begin{array}{l}\text { Tamura, E., et al. (2013). "Effect of pharmacists wearing a mask on } \\
\text { patient consultation intention." Yakugaku Zasshi 133(6): 737-745. }\end{array}$ & Study type \\
\hline 170. & $\begin{array}{l}\text { Tong, P. S. Y., et al. (2015). "Respiratory consequences of N95-type } \\
\text { Mask usage in pregnant healthcare workers-A controlled clinical } \\
\text { study." Antimicrobial Resistance and Infection Control 4(1). }\end{array}$ & Intervention \\
\hline 171. & $\begin{array}{l}\text { Turnberg, W., et al. (2009). "Personal healthcare worker (HCW) and } \\
\text { work-site characteristics that affect HCWs' use of respiratory-infection } \\
\text { control measures in ambulatory healthcare settings." Infection } \\
\text { Control and Hospital Epidemiology 30(1): } 47-52 \text {. }\end{array}$ & $\begin{array}{l}\text { Reported } \\
\text { outcomes }\end{array}$ \\
\hline 172. & $\begin{array}{l}\text { Wada, K., et al. (2012). "Wearing face masks in public during the } \\
\text { influenza season may reflect other positive hygiene practices in } \\
\text { Japan." BMC Public Health 12(1). }\end{array}$ & $\begin{array}{l}\text { Reported } \\
\text { outcomes }\end{array}$ \\
\hline 173. & $\begin{array}{l}\text { Wu, S., et al. (2011). "Anxiety during respirator use: Comparison of } \\
\text { two respirator types." Journal of Occupational and Environmental } \\
\text { Hygiene } 8(3): 123-128 \text {. }\end{array}$ & Study type \\
\hline 174. & $\begin{array}{l}\text { Yip, W. L., et al. (2005). "The effect of wearing a face mask on body } \\
\text { temperature." Hong Kong Journal of Emergency Medicine 12(1): 23- } \\
27 .\end{array}$ & $\begin{array}{l}\text { Reported } \\
\text { outcomes }\end{array}$ \\
\hline
\end{tabular}


Appendix 5. Figure 3. Risk of bias summary: review authors' judgements about each risk of bias item for each included study.

\begin{tabular}{|c|c|c|c|c|c|c|c|}
\hline & 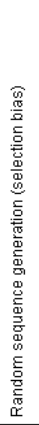 & 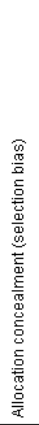 & 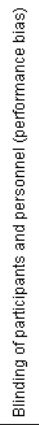 & 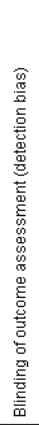 & 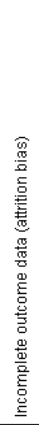 & 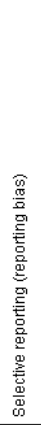 & 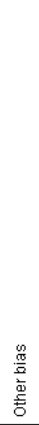 \\
\hline Aiello 2012 & $\odot$ & $\odot$ & $\theta$ & + & + & - & $\odot$ \\
\hline Allison 2010 & $\odot$ & $\theta$ & $\theta$ & $\theta$ & $\theta$ & † & + \\
\hline Baig 2010 & $\odot$ & $\odot$ & $\odot$ & $?$ & ๑ & † & $?$ \\
\hline Barasheed 2014 & $?$ & $?$ & $\odot$ & $?$ & $\odot$ & $\odot$ & $?$ \\
\hline Bryce 2008 & $\theta$ & $\ominus$ & $\Theta$ & $?$ & + & $\odot$ & + \\
\hline Canini 2010 & $\odot$ & $\odot$ & $\Theta$ & $\odot$ & $\odot$ & $\odot$ & $\odot$ \\
\hline Chan 2015 & ○ & - & $\theta$ & $?$ & (†) & † & + \\
\hline Chen 2016 & $?$ & $?$ & ○ & $?$ & (†) & + & $?$ \\
\hline Chughtai 2019 & $\odot$ & ○ & $\theta$ & $?$ & 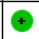 & ๑ & † \\
\hline Cowling 2008 & 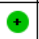 & $\odot$ & $\theta$ & $\theta$ & $\Theta$ & - & † \\
\hline Cowling 2009 & $\odot$ & $\odot$ & $\odot$ & $?$ & $\odot$ & $?$ & + \\
\hline DiLeo 2017 & $\odot$ & $\odot$ & $\odot$ & $\odot$ & + & + & + \\
\hline Foo 2006 & ? & ○ & ○ & $?$ & (†) & + & $?$ \\
\hline Forgie 2009 & ○ & ○ & ○ & $?$ & + & + & $?$ \\
\hline Jacobs 2009 & $?$ & $?$ & ○ & - & (†) & $\theta$ & $?$ \\
\hline Kao 2004 & ○ & ○ & $\theta$ & $\theta$ & + & + & $?$ \\
\hline Larson 2010 & $?$ & $?$ & $\odot$ & $?$ & $\ominus$ & $?$ & $?$ \\
\hline Lee 2011 & ○ & ○ & 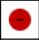 & + & + & (†) & $\odot$ \\
\hline Lim 2006 & $\odot$ & - & $\theta$ & $?$ & (†) & - & $?$ \\
\hline Maclntyre 2009 & $?$ & $?$ & ○ & + & $\odot$ & † & $?$ \\
\hline MacIntyre 2011 & $?$ & (†) & ○ & $\theta$ & 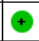 & † & † \\
\hline MacIntyre 2013 & $?$ & $?$ & $\odot$ & $\odot$ & ๑ & $\odot$ & $?$ \\
\hline MacIntyre 2015 & + & † & ○ & ○ & 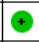 & † & $\odot$ \\
\hline Martel 2013 & ○ & ○ & ○ & $?$ & $\odot$ & $\odot$ & † \\
\hline Nickell 2004 & ○ & ○ & $\theta$ & $?$ & $\odot$ & $\odot$ & $\odot$ \\
\hline Ong 2020 & $\odot$ & $\odot$ & $\theta$ & $?$ & ๑) & $\odot$ & ( \\
\hline Or 2018 & $\odot$ & $\odot$ & $\odot$ & 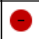 & + & $\odot$ & $?$ \\
\hline Person 2018 & $?$ & $?$ & $?$ & $?$ & + & (†) & + \\
\hline Radonovich 2009 & $?$ & $?$ & ○ & $\theta$ & + & + & + \\
\hline Radonovich 2019 & $\odot$ & † & + & + & † & ๑ & † \\
\hline Rebmann 2013 & $?$ & $?$ & ○ & $\theta$ & + & $\odot$ & $?$ \\
\hline Roberge 2012 & $?$ & అ & ○ & $\theta$ & + & $\odot$ & † \\
\hline Shenal 2012 & $\odot$ & - & $\theta$ & $?$ & - & - & $?$ \\
\hline Simmerman 2011 & $\odot$ & $?$ & $\odot$ & + & + & $\odot$ & $?$ \\
\hline Suess 2012 & $\odot$ & † & $?$ & $\odot$ & († & (†) & (†) \\
\hline Thomas 2011 & 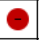 & ○ & $\theta$ & $?$ & + & (†) & $?$ \\
\hline Vanjak 2006 & † & † & $?$ & + & + & (†) & + \\
\hline Wong 2013 & † & † & $\theta$ & $\theta$ & (†) & $\odot$ & + \\
\hline Yeung 2020 & $?$ & ○ & $\theta$ & $\theta$ & ๑ & † & † \\
\hline
\end{tabular}


Appendix 5. Figure 4. Analysis with studies rated at high risk of bias in more than 2 domains excluded

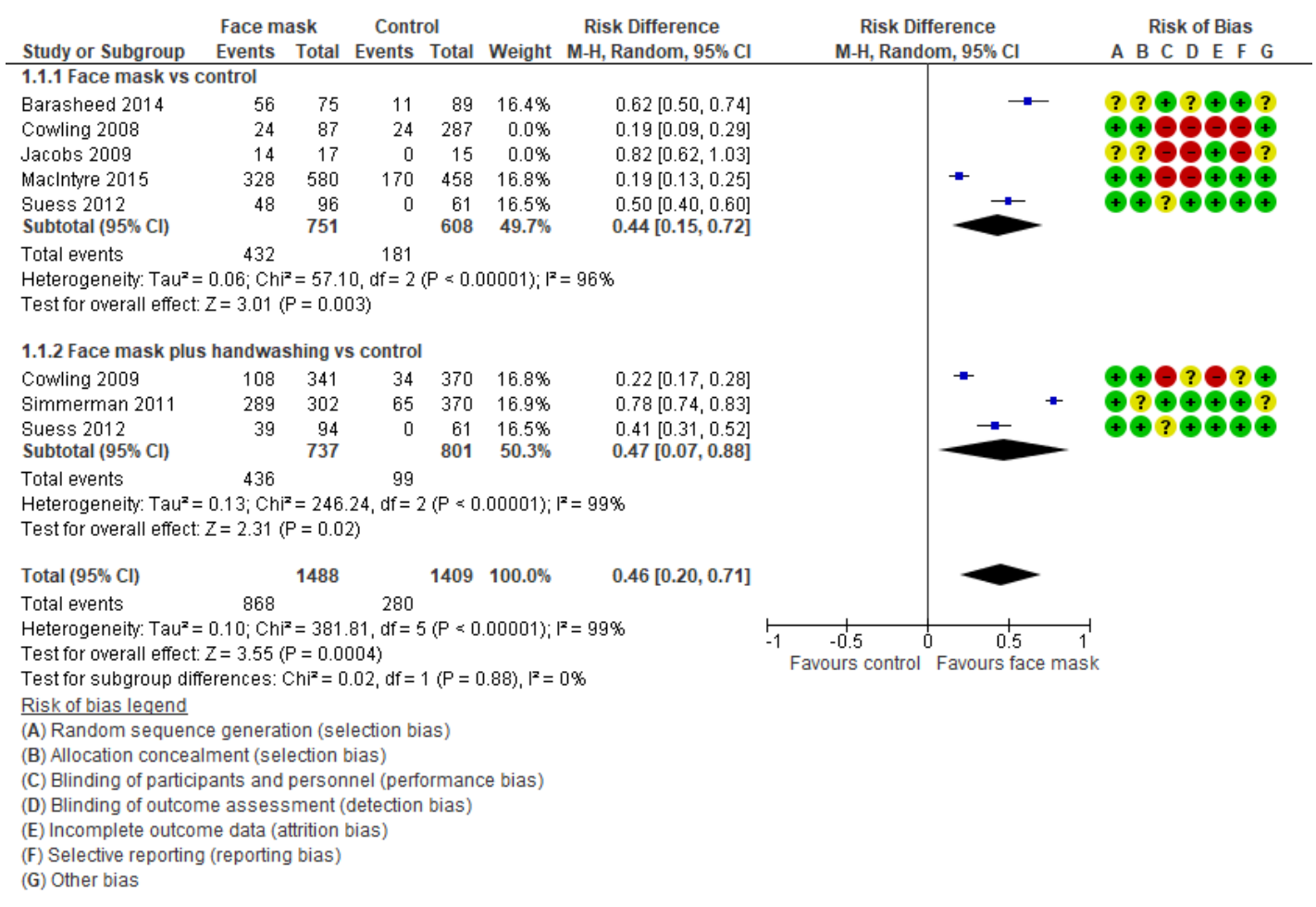

Appendix 5. Figure 5. Analysis with studies sub-grouped by setting (community setting, hospital setting)

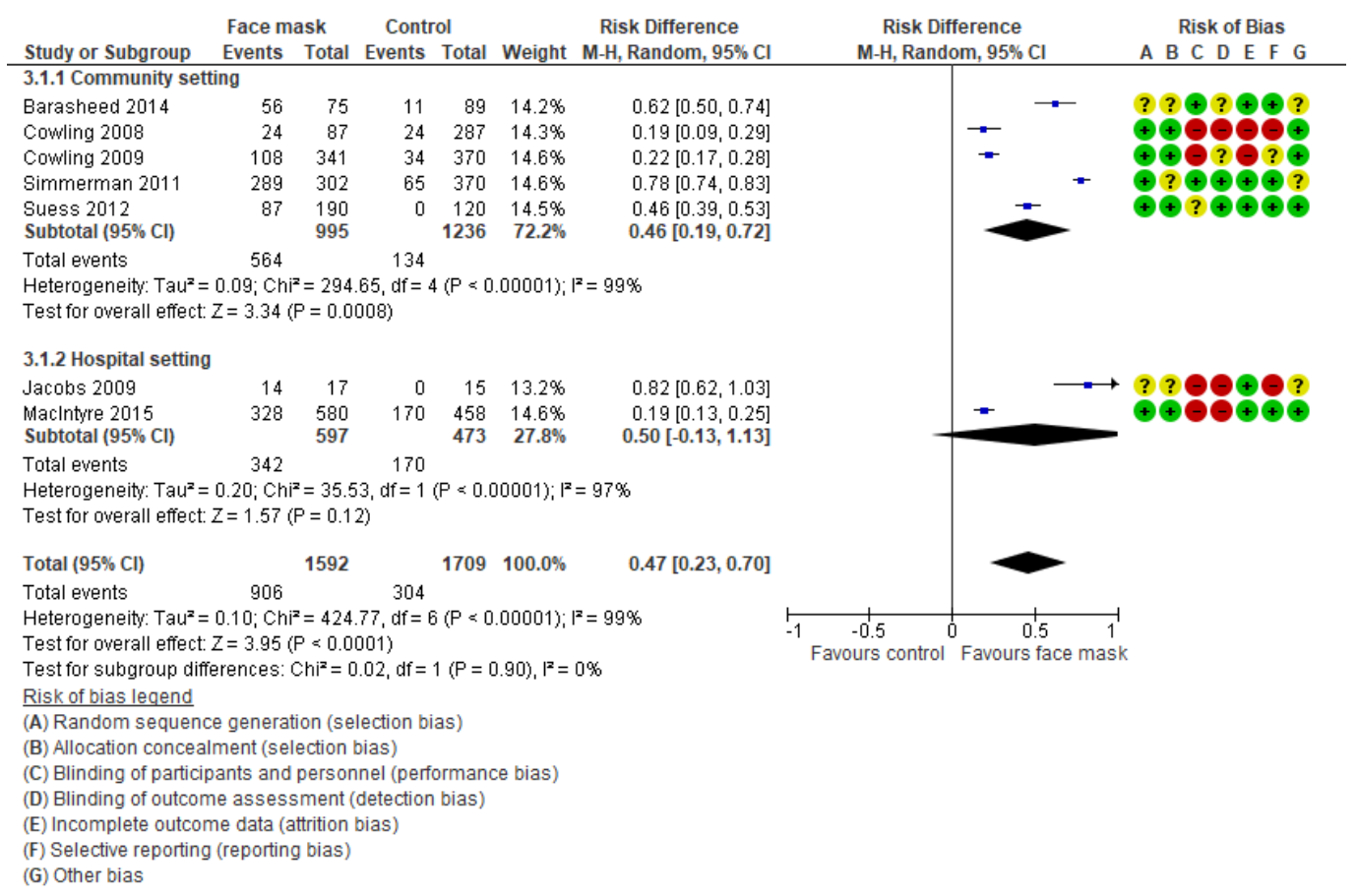

